\title{
The winners of legislative mandate: An analysis of post-parliamentary career positions in Germany and the Netherlands
}

\author{
CLINT CLAESSEN ID, STEFANIE BAILER ID \\ \& TOMAS TURNER-ZWINKELS \\ Department of Political Science, University of Basel, Switzerland
}

\begin{abstract}
Little is known about the careers of parliamentarians after they leave parliament. We analyse the post-parliamentary careers of German and Dutch parliamentarians over the last 20 years and document the presence of a persistent and substantial gender gap. This gap exists regardless of party, country or political position and persists even when the status of the pre-parliamentary profession and achievement within parliament are controlled for. Aside from demonstrating our findings, we offer new insights into possible explanations for the dynamics behind them. Additionally, we show that parliament only serves as a stepping stone for a more successful career for a relatively small share of politicians: only 32 per cent of MPs obtain more attractive positions in the public or private sector after their legislative service.
\end{abstract}

Keywords: career; gender; legislator; profession; post-parliamentary career; Germany; the Netherlands

\section{Introduction}

When female parliamentarians leave their elected mandates and take up positions in the public or business sector, it becomes apparent whether time in parliament has been a stepping or stumbling stone in their careers. Examples of post-parliamentary career success are former Dutch parliamentarian and transport Minister Neelie Kroes, who became the European Commissioner for Competition and Digital Agenda, or former German President of the Bundestag, Rita Süssmuth, who accepted a position as head of a private university in Germany while holding various board positions alongside it. These women demonstrate that parliamentary and cabinet careers can lead to attractive post-parliamentary positions for female parliamentarians. Yet, considering most parliamentarians leave their service as deputies in their mid-50s, when they can still pursue a substantial part of their careers, we still know surprisingly little about where they go after elected service and what role their achievements in parliament play in this. We therefore do not know whether the idea that parliament serves as a stepping stone for attractive positions in the private or public sector for men as well as women is grounded in reality or if it is a myth.

Critical observers extensively discussed the ethics of the 'revolving-door' phenomenon at work here, a term which describes the process of politicians transitioning from the political to the business world, and possibly providing the latter with privileged information acquired when in public office (Vidal et al., 2012). In this study we ask whether there is a discrepancy between the numbers of men and women going into more attractive

Funding for this paper was kindly made possible by Swiss National Science Foundation (SNF 162427). 
positions after a legislative mandate while accounting for achievement before and within parliament. When looking at this discrepancy, we take into account both financial and occupational status components as part of post-parliamentary career positions. We also study achievement as a topic on its own and estimate the value of higher positions within parliament for the obtainment of attractive post-parliamentary positions, thus highlighting the value for non-political employers of the political human capital that is built up in parliament.

Our study offers three key contributions. First, we not only investigate the phenomenon of parliamentarians who move to positions after their parliamentary career but also scrutinize what explains these moves. Second, we are the first to investigate the relationship between gender, achievement and the attractiveness of post-parliamentary employment with detailed individual level career data. We furthermore make a distinction between public and private sector positions, as the dynamics we investigate might not only hold for private sector employment. Third and finally, we take into account pre-parliamentary achievement (i.e., a high status job before entry into parliament) which arguably might lead to both attractive positions within parliament, as well as attractive post-parliamentary employment. Notably, our study avoids omitted variable bias by including a detailed measure of politicians' social economic status upon entry into parliament. Taken together, this approach fills a key research gap when it comes to the currently unknown relationship between legislative careers and post-parliamentary careers and the risks involved in taking up a career in politics for men and women.

An investigation into the whereabouts of ex-parliamentarians has several normative implications for the functioning of democratic societies. On the one hand, we may worry about the revolving-door phenomenon mentioned above, in which public officials go on to work in areas they previously regulated (Hudon \& Yates 2016). Second, when in office, it is possible that parliamentarians develop an interest in serving those who might later offer them attractive employment, for example, businesses or foundations, instead of serving the interests of those who elected them. Citizens' trust in politics and governance can be severely affected if MPs have possible conflicts of interest. If parliamentarians serve potential future employers instead of their ideological principles - presumably the values that won them the support of voters - then the representation link is damaged. Third, the quality of post-parliamentary employment - and not just an MP's salary during their mandate - may impact the quality of candidates and parliamentarians that a legislature is able to attract. Elected officials are very aware of the fact that their career can end abruptly, leading to a rather widespread feeling of job insecurity among parliamentarians (Borchert $\&$ Stolz, 2003). If employment after the mandate is attractive, a more diverse and more qualified group of candidates will consider running. Hence, if it can be shown that the legislative mandate is a stepping stone for some parliamentarians and a stumbling block for others, we may explain why some people are not attracted to service in the legislature (e.g. women or business people).

Applying new data, our results show that an attractive post-parliamentary career depends not only on achievement in parliament but also on gender. We show that men fare distinctly better in obtaining interesting and well-paid positions in the job market after their time in parliament. This is a particularly interesting finding considering that the women of interest in this study already represent a select group who are not risk-averse or daunted 
by competition, especially since the latter functions as a frequent explanation for the low numbers of women at the candidacystage.

\section{Post-parliamentary external employment}

Building on a limited but growing literature that looks into the post-parliamentary whereabouts of parliamentarians (see Baturo \& Mikhaylov 2016; Byrne and Theakston, 2016; Freund \& Bendel, 2016; Würfel, 2017), we seek to identify which factors make parliamentarians attractive for the post-parliamentary job market. As a baseline we assume that parliamentarians are, also after their legislative mandate, driven by personal ambition and a desire to influence social, economic and political life. They will continue to strive for positions that are attractive either in terms of reputation or financial remuneration. Yet, obtaining attractive post-parliamentary positions is constrained by personal limitations. Examples of this are health and age. There are also demand side constraints, such as a labour market with a limited number of positions in the public or private sector, and a desire from future employers for certain experiences as MPs also play a role. More specifically, we believe that the value in hiring a former parliamentarian in both public and private job markets is particularly based on gender and achievement during their time in parliament. Previous literature on gender in political recruitment has mostly used Norris and Lovenduski's (1995) supply and demand model to investigate whether the supply side leads to the discrepancy in numbers (women do not enter the political arena as frequently as men) or whether it is the demand side of the political system which discriminates against women (for a more encompassing overview of factors at the macro-, meso- and micro-level, see Wägnerud 2009).

\section{Gender and post-parliamentary employment}

When it comes to the supply side, it has been found that women are less likely to run for office because they have a greater aversion to campaigning (Fox \& Lawless, 2004; Lawless \& Fox, 2005) and elections (Kanthak and Woon, 2014; Preece and Stoddard, 2015) because they are less ambitious, and because they are socialized to avoid conflict and competitive surroundings (Croson and Gneezy, 2009; Schneider et al., 2016). However, these arguments refer to women who are considering becoming candidates, whereas the pool of women we investigate consists of experienced parliamentarians and is thus a subset of women who have already overcome any aversion to risk or competition (or never had one). These female parliamentarians have all faced numerous elections and career battles, so it is unlikely that they are less keen than men to search for an attractive position after their mandates. Besides, recent research has shown that women in office are just as interested in higher positions as men are (DavidsonSchmich, 2015).

Hence, the reasons for fewer women may instead be found on the demand side (Jalalzai and Krook, 2010). Some factors which have been found to be negative for women's political career success may also be detrimental for their post-parliamentary careers. We expect to uncover certain challenges for women in both public and private post-parliamentary job markets, such as selection according to similarity and women's relatively speaking weaker network positions. We know that in general, selection committees prefer to recruit 
people who are similar to themselves (Lovenduski, 1986; Jaffé et al., 2019). Hence 'male buddies' are advantaged in contrast to women (Crowder-Meyer, 2013; Fox and Lawless, 2014). Such in-group bias of male-dominated boards against incoming women has been documented extensively for corporate boards in the business sector (Branson, 2006; Rhode and Packel, 2014), but there is little reason to expect a different dynamic for public boards or selection committees. Resulting from this 'insider selection' is that high-trust networks are often closed to women (Gains and Annesley, 2010) and/or that women are excluded from information networks (Lyness and Thompson, 2000). In line with this dynamic is the observation that women are less successful in job markets where informal recommendations and cronyism dominate in contrast to job markets where external, objective, third-party certificates such as academic degrees are rewarded (Estevez-Abe, 2006). The effect of selection according to similarity and women's relatively weak network position apply to both public and private sectors.

Some dynamics are likely to be specific to the public sector. In particular, we gather that women may lose out on support through party patronage. Women are still not close to the power resources inside the party (Childs, 2013), so that they benefit less than men from party patronage (Verge and Claveria, 2016) where parties nominate party members for positions in public or semi-public life (Kopecký et al., 2012, for a different finding see however Claveria and Verge, 2015). As a result of party patronage, women have fewer chances of obtaining highly desirable jobs in the party. They are also offered less attractive portfolios and less powerful roles in government (Escobar-Lemmon and Taylor- Robinson, 2009). This same dynamic is likely relevant for the public post-parliamentary job market where party patronage may still provide links to political foundations and public associations where attractive positions areavailable.

For the private post-parliamentary job market, additional mechanisms may apply. While party patronage may be less important in this sector, a gender hostile corporate culture may be more prevalent and hence negative for women's career success (Devillard et al., 2014). Several management studies analyse and discuss how role perceptions and organizational structures in business generate bias (Ely and Padavic, 2007; Ryan and Haslam, 2007) so that particularly in the business sector, a perceived incongruity between a woman's social role and the demand for leadership associated with masculinity can be an additional hurdle for women (Glass and Cook, 2016).

\section{Achievement and post-parliamentary employment}

Besides possible gender dynamics, employers in the public and private sector have been found to hire personalities with a certain level of political achievement due to outstanding ministerial or party leadership positions. The revolving-door literature (Vidal et al., 2012; Lazarus et al., 2016; Baturo and Arlow, 2017) outlines that one key reason for why former parliamentarians and ministers move into public and private sector positions is because these employers appreciate their political human capital, that is, their contacts, experience and knowledge (Claveria and Verge, 2015). The leadership experience or political capital acquired during their time in parliament might not only matter for leadership positions inside parliament (Marsh, 1993, Strøm, 1993) but also for positions outside parliament. Moreover, foundations, boards and companies may want to benefit from their experience, 
but also their reputation as former high-profile politicians. Political achievement also often comes with policy expertise and knowledge gathered in certain specialized committees (Luechinger and Moser, 2014). This is also considered an asset to future private and public employers (Theakston, 2012). As such, parliamentarians with extensive political experience and strong networks have been known to be able to take better advantage of attractive employment opportunities after their mandate (Diermeier et al., 2005, Bertrand et al., 2011). For example, in the United States it has been shown that serving in higher political office increases the chances of working in a corporate board by 30 per cent (Palmer and Schneer, 2016). Positive achievements within parliament are thus likely to translate into attractive post-parliamentary employment.

A parliamentary career can furthermore contain elements of negative achievement. If a politician is forced to leave parliament due to a missed re-nomination for a seat, or due to a failed election, he or she has suffered an open defeat and might carry the stigma of failure. In particular, the obtainment of attractive public sector jobs might be affected by losing the 'seal of approval' from the party elite and thus the patronage network that comes with it. Another effect could be that parliamentarians who plan their departures carefully may benefit from a longer window for contacting potential employers, or may even decide to end their mandate earlier due to more attractive outside options. ${ }^{1}$ Here, we break down achievement and measure two key components: what was achieved before the legislative mandate (i.e., occupational status) and the status that an MP achieved during her time in parliament (i.e., cabinet positions, higher party positions). Controlling for achievement is furthermore important for testing a 'clean' gender effect. When achievement is not taken into account, gender might seem more important than it actually is because achieving higher positions in the (pre-)parliamentary phase might be harder for female politicians.

\section{Other factors that need to be taken into account}

In addition, we consider the business expertise and ideological orientation of MPs, for which we need to statistically control. In particular, we look at post-parliamentary employment in the business sector (Würfel, 2017). Parliamentarians who have gathered expertise in committees related to business and financial affairs may have attractive insider knowledge, from which companies may benefit. Vaubel et al (2012) found, for example, that ex-European Union Commissioners are particularly able to find attractive employment when they have been in charge in the areas of competition, internal markets, industry or taxation, as these are areas relevant for businesses.

Ideologically, right-wing or liberal politicians are considered more attractive to the private sector than their more left-wing colleagues (Anderson, 2010). Similarly, Theakston (2007) found in the United Kingdom that Conservative former MPs used their networks to a larger extent to find employment than their Labour colleagues, and Eggers and Hainmüller (2009) showed that British Conservatives could translate their parliamentary network experience and connections into lucrative post-parliamentary directorships and consulting positions, while their colleagues from Labour could not. The reasoning for the ideological match between MPs and businesses might simply be one of decreased costs. Companies may prefer to cooperate with former MPs who share their values and their probusiness orientation. Furthermore, MPs with experience in business-related politics may 
provide better contacts to relevant actors in the political sector. We will account for this ideological orientation by measuring the free-market orientation of the party to which an MP belongs.

\section{Hypotheses}

Based on our considerations with regard to the demand and supply side of the political system, we expect men to obtain more attractive post-parliamentary positions than women. Our study also addresses this interplay between achievement and gender. To investigate whether parliament is a stumbling block for women, we want to know whether attractive post-parliamentary employers are themselves biased against hiring women. An alternative situation would be that post-parliamentary employers just reproduce inequality in the previous political career. The real test of our theory is therefore a condition, in which both pre-parliamentary achievement (education, occupational status), as well as parliamentary achievement (cabinet or other leadership position) are statistically controlled for:

H1: Male MPs have a higher probability of obtaining attractive post-parliamentary positions than women in both private and public sectors, even when (pre-) parliamentary achievement is controlled for.

In addition, we expect parliamentarians to obtain attractive post-parliamentary employment when they did well in parliament. One key indicator of achievement in parliament is high positions in a party, parliament or cabinet. Such positions make it easy for later employers to identify successful candidates.

H2: Parliamentarians with substantial political achievement, such as higher positions in the party, parliament or cabinet have a higher probability of obtaining attractive post-parliamentary positions in the private and public sectors than those without these positions.

$\mathrm{H} 2$ tests achievement with a positive indicator. Yet, if our reasoning is correct then negative political achievement should also negatively predict attractive post-parliamentary employment. MPs who are forced to end their mandate in an unplanned fashion due to a failure to be re-nominated or re-elected might carry the stigma of failure and thus have a more diminished reputation than MPs who consciously choose to leave parliament. This offers an additional way to test the robustness of an achievement effect.

H3: Parliamentarians who have failed to be re-nominated or re-elected have a lower probability of obtaining attractive post-parliamentary positions.

\section{Case selection and datasets}

The choice of the two established parliamentary systems of the German Bundestag and the Dutch Tweede Kamer provides an opportunity for generalizable findings across similar Western European democracies. Both parliaments are professional, full-time legislatures with similarly strong legislative power (see their high and similar rating in the Parliamentary 
Power Index by Fish and Kroenig, 2009), with powerful parties that offer adequate salaries so that candidates desire to stay as long as possible if they do not obtain more attractive positions (Secker, 1995; Borchert and Stolz, 2011). In both of our cases, the German Bundestag and the Dutch Tweede Kamer, there are no regulations concerning cooling off periods, so that these cases facilitate our analysis of post-parliamentary positions among MPs. In addition, Germany and the Netherlands can be considered coordinated economies (Hall and Soskice, 2001), in contrast to more free-market oriented economies such as the United States and the United Kingdom, where we already have more knowledge about post parliamentary careers (Vidal et al., 2012; Baturo and Mikhaylov, 2016; Byrne and Theakston, 2016). Also, both countries have well-documented parliamentary biographies of their parliamentarians, and therefore high-quality data. We extend these data further by hand-coding new data on post-parliamentary careers using several resources including online media, and biographies, as well as the documentation centre for Dutch parliamentarians.

We merged two datasets that coded the biographies of both the Bundestag (Würfel, 2014) and the Dutch Tweede Kamer (Claessen, 2015). The combined dataset contains 1,413 MPs who left parliament: 792 MPs from Germany that left between 1998 and 2013, and 621 Dutch parliamentarians that left between 1983 and 2015. From these data, we used all 1,351 MPs for whom we could find reliable information on their post-parliamentary employment. ${ }^{2}$ Of this slightly reduced subset, 42.2 per cent $(n=570)$ were found to have moved into the public sector and 57.8 per cent $(n=781)$ into the private sector.

\section{Measuring attractive post-parliamentary positions}

When it comes to more attractive employment after leaving parliament, our focus is on career success. ${ }^{3}$ We use post-parliamentary positions that are based on datasets that code the biographies of both the Bundestag (Würfel, 2014) and the Dutch Tweede Kamer (Claessen, 2015). In essence, the data on actual career political positions are directly observable and verifiable. Post-parliamentary positions were coded as follows: all parliamentarians that left in the given periods received a code for the position they obtained within five years of leaving parliament. We assume that after this time period postparliamentary jobs can no longer justifiably be attributed to the effects of the mandate. Of all the positions that a parliamentarian held in the respective period, the most prominent post-parliamentary position is evaluated on the basis of two criteria.

First, if salary levels were available, we compared them with the parliamentary salary level. Next, on the basis of the status of the occupation, the post-parliamentary position obtained a 2 if experts considered them more attractive, a 1 if equally attractive or a 0 if less attractive compared to the parliamentary position. The latter two categories ( 1 and 0 ) were then collapsed for the analysis to contrast those who fare better than others. An extensive description can be found in the first part of the online appendix. For all positions there is a distinction between public and private positions since the sectors might have different employment dynamics for the following reasons (see also Tables A2 and A3 in the Online Appendix). ${ }^{4}$ First, particularly for the private sector, we considered it important to control for the effect of having served in a business-related parliamentary committee and a business-friendly party. We expect a positive effect of these variables in the case of positions 
in the private sector, but not in the public sector, which is best dealt with by distinguishing between these two sectors as two samples. Second, it is an open question whether the mechanisms leading to discrimination in these two sectors are similar or different. While the public sector, for example, in the case of parties, uses quotas to correct for discrimination, discussion on quotas and gender diversity are no strangers to corporate boardrooms either; consequently Norway and Spain introduced quotas for female directors in listed companies (see, e.g., the Davies review (2011)). Third, also the effect of informal promotion to postparliamentary positions via party patronage networks may be similar or varying in both sectors. The party leadership may have good connections to both public and private sectors - also depending on the party orientation - so that we cannot say for sure whether party patronage is effective for one of these sectors only. Hence, we distinguish between those two models to detect different mechanisms. Fourth, the negative effect of gender hostile corporate culture may be stronger in the private sector, and hence more detrimental to women's career success (Devillard et al., 2014). Distinguishing between these two sectors helps to detect these different mechanisms.

We assured reliable coding in several ways. First, the coding method was subject to intercoder reliability tests in both the Netherlands and Germany. Three coders with different backgrounds from the business sector and political science were given a random sample of German cases. Similarly, for the Netherlands, three coders (one from the medical field, one from a governmental statistics bureau and one political science student) were given a random sample of German cases. The percentage of agreement ranged between 75 and 93 per cent (see Table A1 in the Online Appendix). Besides looking at a random sample for reliability, the different coders also reviewed a small set of critical cases for both Germany and the Netherlands. This subset included parliamentarians whose post- parliamentary success was not straightforward. In these cases, we took the most common coding.

\section{Explaining post-parliamentary employment: the independent variables}

The first hypothesis concerning gender is measured as a dummy variable (male/female). To study the effect of gender in detail, we also investigate whether the main effect of gender remains significant after adding controls for the achievement before and during the mandate. Pre-parliamentary experience consists of both professional and political experience. In order to integrate the professional experience, we measured the highest occupational status they had before entering parliament using the International Socio- Economic Index (ISEI) of occupational status. ${ }^{5}$ This measure, developed by Ganzeboom et al. (1992; http://www.harryganzeboom.nl/isco08/), is an established tool for sorting national occupational classifications into a common coding, and it measures the value society assigns to occupational positions. In order to account for pre-parliamentary political experience, we include years of party membership before entering parliament. ${ }^{6}$ We also include a binary control variable that measures higher education (yes/no). Together, these two measures allow us to account for the prestige and the attractiveness of positions held before serving as parliamentarians in Germany and the Netherlands.

The second hypothesis concerning political achievement is captured by the various positions a parliamentarian held, for example membership in the presidium of the legislative 
chamber (yes/no) in the last term, a party position (yes/no) either in the party executive or in the party presidium, or membership in the cabinet (yes/no) in the last two terms.

The third hypothesis measures the manner of leaving, which is captured by two binary variables failed re-election and failed re-nomination that indicate whether the parliamentarian in question left due tofailed re-election (yes/no) or re-nomination (yes/no). This information was gathered from national and local online media sources which were consulted for each politician. We also include the age of a parliamentarian at the time of exit to account for less interest in attractive post-parliamentary employment due to age-related reasons. This variable provides a viable alternative to the 'retirement' variable from the career literature(Frantzich, 1978; Theriault, 1998; Raymond etal., 2016). Namely, voluntary retirement is an unreliable measure, but age at exit is not.

We include several control variables that are not of immediate theoretical interest to us but important for the internal validity of our results. The first of these is years as an MP. This is not in itself a measure of achievement as it also includes long-term backbenchers. It is, however, a measure for intra-parliamentary experience. Second, in order to account for subtler differences in terms of political access, we include two variables that are measured on the party level: business-friendly party and party in power (yes/no). Possibly business actors are interested in gaining access to political actors in order to promote their special interests, in short, to lobby for their causes. In some cases it may even lead to direct benefits such as procurement contracts (Goldman et al., 2009) or more favourable loans from government banks (Mian and Khwaja, 2004; for an overview of this literature see also Eggers and Hainmüller, 2009). Accordingly, former parliamentarians from parties that are still in power might be particularly attractive among lobbyists since they provide access to the current government (Eggers, 2010; Bertrand et al. 2011). Our first indicator measures how business friendly the MP's party was during their last term. This variable is based on the (standardized) score on the free-market orientation index of the MP's party. It is derived from the party manifesto project (https://manifestoproject.wzb.eu/). The second variable party in power (yes/no) measures whether the MP's party is currently in power and thus whether they have access to the governing parties. Lastly, we also include business committee (yes/no) in order to measure whether the MP was part of a parliamentary committee related to business and thus has important knowledge or personal network capital for private employers.

Other more confounding effects have to do with age and cohort effects. One such control variable is the period in which a parliamentarian was in office. This is operationalized by the year of exit (e.g., the last legislative term the parliamentarian was in office). Moreover, to account for possible retirement due to old age, we also included age at exit. For an overview of the variables used, see Table A4 in the Online Appendix.

The analysis will be completed in two steps. First, descriptive evidence is used to give a general overview of the dependent variable, the main gender differences and some country differences. Second, we will use several logistic regression models to test our key hypotheses. In order to test our three hypotheses, independent and control variables are introduced separately and evidence is given at the highest generalizable level. This entails hypothesized effects that hold overall, while effects that only hold in the public or in the private sector are more dissected. 

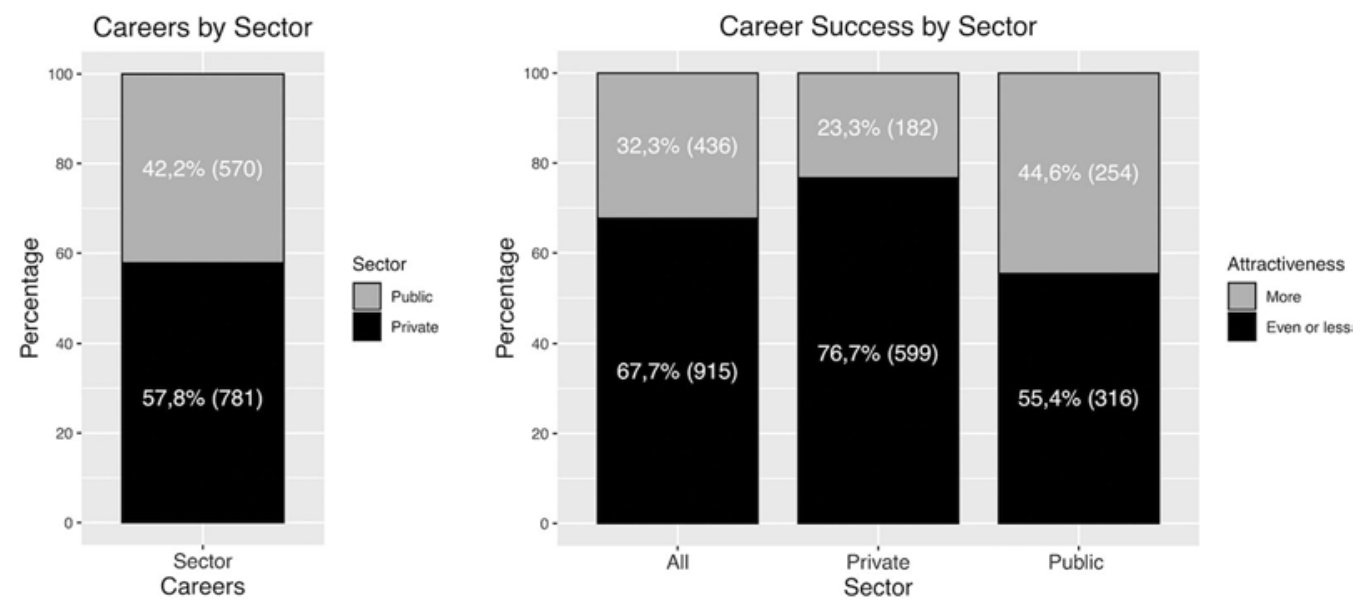

Figure 1. Number and percentage of parliamentarians entering the public and private sector after parliament, second chart by attractiveness (absolute numbers in parentheses).

\section{Descriptive results}

The results show that parliament serves less as a stepping stone than some examples cited in the media suggest. Interestingly, for the majority of MPs, the loss of a parliamentary seat means accepting a similarly or less financially attractive position. Figure 1 shows that of the 1,351 Dutch and German MPs in our data, only 32.3 per cent (ㅁ436) found more attractive employment in their post-parliamentary careers.

Our data furthermore show some sectoral differences. Indeed, when it comes to the differences between moving to either public or private sector, 42.2 per cent (n 570) of all parliamentarians move into the public sector and 57.8 per cent $\left(n_{=} 781\right)$ to the private sector. When we look at parliamentarians in these sectors, of all the MPs who went into the public sector, 44.6 per cent (n 254) found a more attractive position, whereas only 23.3 per cent $(n=182)$ found more attractive positions in the private sector. Given our key interest in gender, we continue with a breakdown of our key dependent variable (obtaining more attractive positions, yes 1 , no 0 ) for both genders (see Figure 2).

Figure 2 suggests that women indeed face difficulties in obtaining attractive postparliamentary employment as we hypothesised. For women, 24.0 per cent (n 105) who leave office obtain a more attractive position, whereas for men that percentage is at 36.2 per cent (n 331). This constitutes a gap of 12.2 per cent. In Figure 2 we also look at this gap broken down by job market. For the public sector, the difference between male and female parliamentarians that obtain more attractive employment is around 13.1 per cent. In the private sector it is around 11.0 per cent.

Besides gender, we are also particularly interested in the role played by achievement in parliament in obtaining an attractive position after parliament. Following our analytical rational, we scrutinize these differences in the public and private sector separately in Figure 3 .

The descriptive results for the public sector suggest a strong effect for all of our achievement variables. We can see in Figure 3 that (1) former cabinet members, (2) 

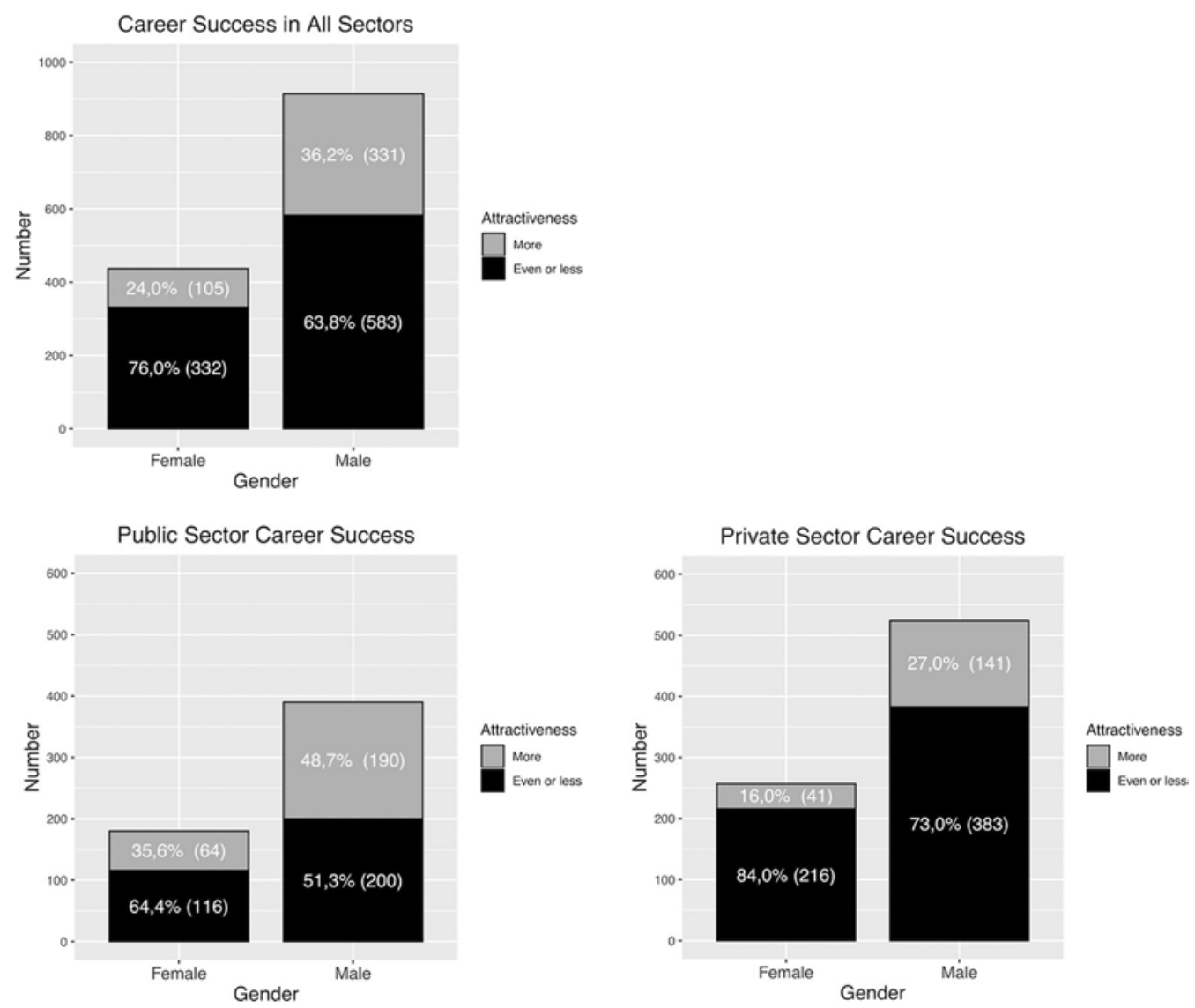

Figure 2. Percentage of parliamentarians entering attractive positions after leaving parliament, by gender and by sector (absolute numbers in parentheses).

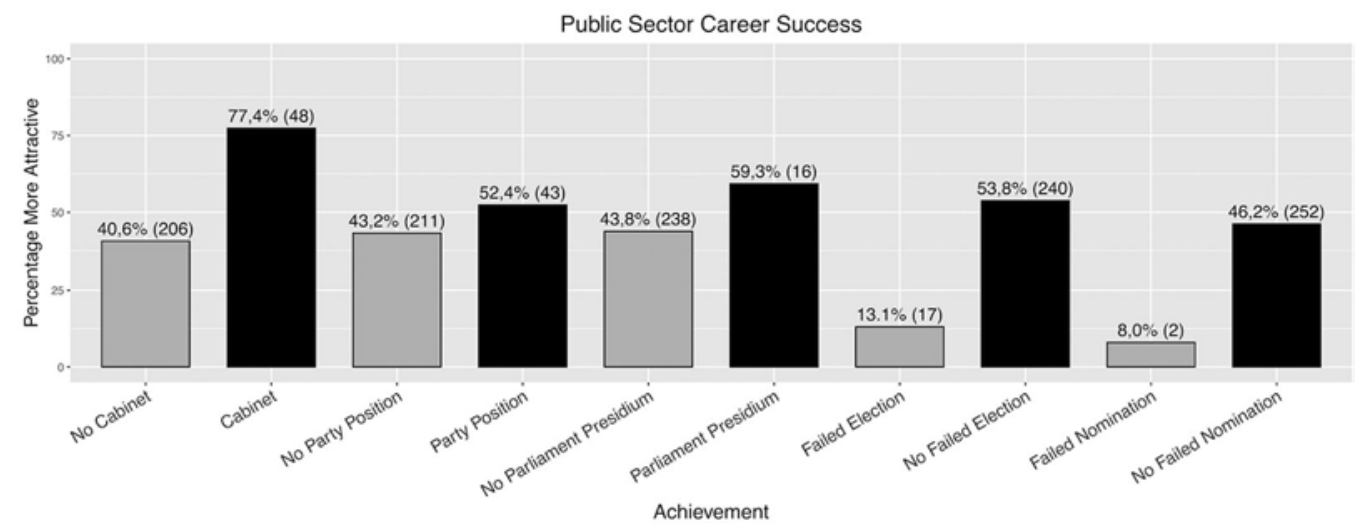

Figure 3. Percentages of parliamentarians obtaining more attractive public post-parliamentary career positions according to achievement variables. 


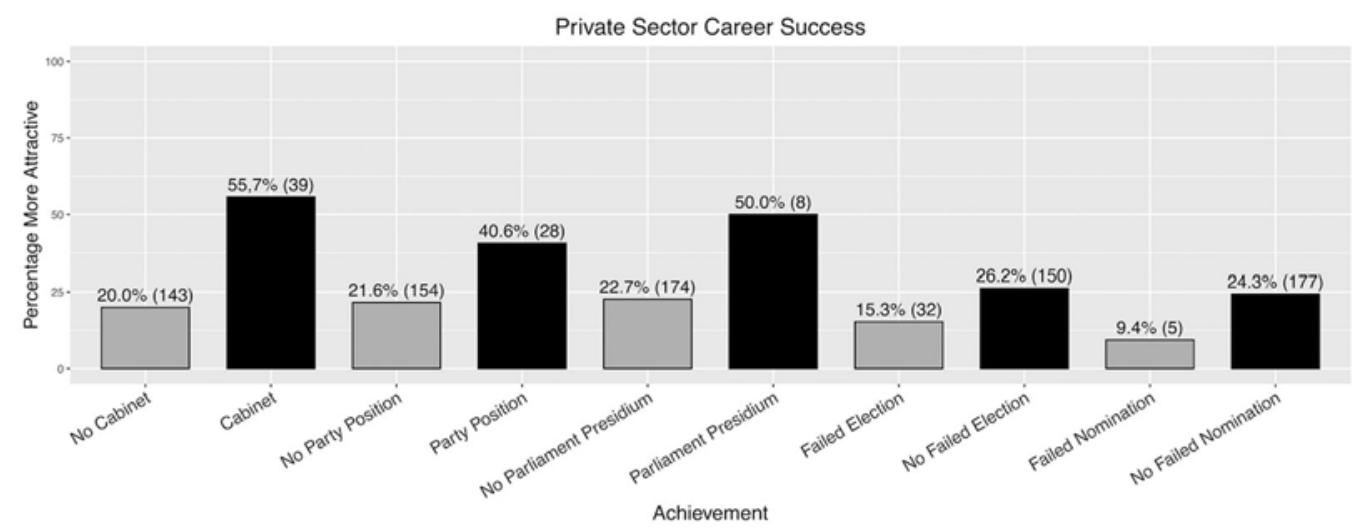

Figure 4. Percentages of parliamentarians obtaining more attractive private post-parliamentary career positions according to achievement variables.

parliamentarians in the party executive or presidium and in the (3) presidium of the parliament all have a higher percentage chance of obtaining more attractive public positions. The observed differences in Figure 3 are stark: the gap between cabinet members and non-cabinet members is 36.8 per cent (77.4-40.6 per cent), whereas the difference between parliamentarians with and without a party position is 9.2 per cent (52.4-43.2 per cent). Interestingly, however, the biggest difference reveals itself when it comes to our negative indicator of achievement. The observed percentage of those failing re-election is 13.1 per cent versus 53.8 per cent for those who do not. This constitutes a difference of 40.7 per cent. This gap is 38.2 per cent for those that fail re-nomination. The results in the private sector (Figure 4) are similar.

Those who were (1) a member of the cabinet, (2) had a party position in the executive or the presidium or (3) took seat in the parliament presidium have a much higher share of attractive post-parliamentary private sector positions. 55.7 per cent of cabinet members obtained a more attractive private sector position, whereas only 20.0 per cent of noncabinet members did so, which leaves a gap of 35.7 per cent. These differences remain consistent throughout the achievement variables. Interestingly, the relative gaps for negative achievement in the private sector are smaller than they are for the public sector. The gap between those with an executive or presidium position in a party or the parliament, and those without is a bit larger for the private sector, namely, a gap of 19.0 per cent for party positions and a gap of 27.3 per cent for the parliament presidium. With this descriptive image in mind, we turn to the analysis of the hypotheses.

\section{Regression results}

In order to test our expectations we ran a series of logistic regression models with a more attractive post-parliamentary position in the public or private sectors as dependent variable (see Table 1).

The models seem to confirm the first hypothesis concerning the gender gap of postparliamentary employment. There is a pronounced gender gap for both public and private 
Table 1. Logistic regression models of post-parliamentary career success

\begin{tabular}{|c|c|c|c|c|c|c|}
\hline & $\begin{array}{c}\text { Public } \\
\text { Model } 1\end{array}$ & $\begin{array}{c}\text { Public } \\
\text { Model } 2\end{array}$ & $\begin{array}{l}\text { Public } \\
\text { (AME) }\end{array}$ & $\begin{array}{l}\text { Private } \\
\text { Model } 3\end{array}$ & $\begin{array}{l}\text { Private } \\
\text { Model } 4\end{array}$ & $\begin{array}{l}\text { Private } \\
\text { (AME) }\end{array}$ \\
\hline Gender (female) & $\begin{array}{l}-0.61^{* * *} \\
(0.23)\end{array}$ & $\begin{array}{l}-0.52^{* *} \\
(0.24)\end{array}$ & $\begin{array}{l}-0.12^{* *} \\
(0.05)\end{array}$ & $\begin{array}{c}-0.78^{* * *} \\
(0.21)\end{array}$ & $\begin{array}{c}-0.67^{* * *} \\
(0.22)\end{array}$ & $\begin{array}{c}-0.10^{* * *} \\
(0.03)\end{array}$ \\
\hline Cabinet & $\begin{array}{l}1.33^{* * *} \\
(0.35)\end{array}$ & $\begin{array}{l}1.23^{* * *} \\
(0.36)\end{array}$ & $\begin{array}{l}0.30^{* * *} \\
(0.08)\end{array}$ & $\begin{array}{l}1.24^{* * *} \\
(0.27)\end{array}$ & $\begin{array}{l}1.23^{* * *} \\
(0.29)\end{array}$ & $\begin{array}{l}0.24^{* * *} \\
(0.07)\end{array}$ \\
\hline Party position & $\begin{array}{c}0.35 \\
(0.29)\end{array}$ & $\begin{array}{c}0.43 \\
(0.30)\end{array}$ & $\begin{array}{c}0.10 \\
(0.08)\end{array}$ & $\begin{array}{l}0.97^{* * * *} \\
(0.30)\end{array}$ & $\begin{array}{l}0.99^{* * *} \\
(0.31)\end{array}$ & $\begin{array}{c}0.19^{* * *} \\
(0.07)\end{array}$ \\
\hline Parliament presidium & $\begin{array}{c}0.44 \\
(0.49)\end{array}$ & $\begin{array}{c}0.47 \\
(0.53)\end{array}$ & $\begin{array}{c}0.12 \\
(0.12)\end{array}$ & $\begin{array}{c}0.96^{*} \\
(0.53)\end{array}$ & $\begin{array}{c}0.85 \\
(0.55)\end{array}$ & $\begin{array}{c}0.16 \\
(0.13)\end{array}$ \\
\hline Failed election & $\begin{array}{c}-2.30^{* * *} \\
(0.30)\end{array}$ & $\begin{array}{l}-2.23^{* * *} \\
(0.32)\end{array}$ & $\begin{array}{l}-0.43^{* * *} \\
(0.04)\end{array}$ & $\begin{array}{c}-0.97^{* * *} \\
(0.25)\end{array}$ & $\begin{array}{c}-0.90^{* * *} \\
(0.28)\end{array}$ & $\begin{array}{l}-0.12^{* * *} \\
(0.03)\end{array}$ \\
\hline Failed nomination & $\begin{array}{l}-2.47^{* * *} \\
(0.78)\end{array}$ & $\begin{array}{l}-2.47^{* * *} \\
(0.75)\end{array}$ & $\begin{array}{l}-0.38^{* * *} \\
(0.05)\end{array}$ & $\begin{array}{l}-1.28^{* *} \\
(0.54)\end{array}$ & $\begin{array}{c}-1.18^{* *} \\
(0.57)\end{array}$ & $\begin{array}{l}-0.13^{* * *} \\
(0.04)\end{array}$ \\
\hline Age at exit & $\begin{array}{c}-0.04^{* * *} \\
(0.01)\end{array}$ & $\begin{array}{c}-0.04^{* *} \\
(0.01)\end{array}$ & $\begin{array}{c}-0.01^{* *} \\
(0.003)\end{array}$ & $\begin{array}{c}-0.05^{* * *} \\
(0.01)\end{array}$ & $\begin{array}{c}-0.07^{* * *} \\
(0.01)\end{array}$ & $\begin{array}{c}-0.01^{* * *} \\
(0.002)\end{array}$ \\
\hline ISEI & $\begin{array}{l}0.35^{* * *} \\
(0.10)\end{array}$ & $\begin{array}{c}0.21^{*} \\
(0.12)\end{array}$ & $\begin{array}{c}0.04^{*} \\
(0.02)\end{array}$ & $\begin{array}{c}0.17^{*} \\
(0.10)\end{array}$ & $\begin{array}{c}0.10 \\
(0.10)\end{array}$ & $\begin{array}{c}0.02 \\
(0.02)\end{array}$ \\
\hline Business-friendly party & & $\begin{array}{l}0.27^{* *} \\
(0.12)\end{array}$ & $\begin{array}{l}0.05^{* *} \\
(0.02)\end{array}$ & & $\begin{array}{c}0.11 \\
(0.11)\end{array}$ & $\begin{array}{c}0.02 \\
(0.02)\end{array}$ \\
\hline Party not in power & & $\begin{array}{c}0.03 \\
(0.22)\end{array}$ & $\begin{array}{c}0.01 \\
(0.05)\end{array}$ & & $\begin{array}{r}-0.22 \\
(0.22)\end{array}$ & $\begin{array}{r}-0.03 \\
(0.03)\end{array}$ \\
\hline Business committee & & $\begin{array}{c}0.19 \\
(0.32)\end{array}$ & $\begin{array}{c}0.05 \\
(0.08)\end{array}$ & & $\begin{array}{l}1.01^{* * *} \\
(0.29)\end{array}$ & $\begin{array}{l}0.19^{* * * *} \\
(0.06)\end{array}$ \\
\hline Years as an MP & & $\begin{array}{c}0.001 \\
(0.02)\end{array}$ & $\begin{array}{c}0.00 \\
(0.003)\end{array}$ & & $\begin{array}{c}0.05^{* * *} \\
(0.02)\end{array}$ & $\begin{array}{c}0.01^{\text {*** }} \\
(0.002)\end{array}$ \\
\hline Party membership & & $\begin{array}{c}-0.01 \\
(0.01)\end{array}$ & $\begin{array}{c}-0.002 \\
(0.002)\end{array}$ & & $\begin{array}{c}0.02^{*} \\
(0.01)\end{array}$ & $\begin{array}{c}0.003^{*} \\
(0.002)\end{array}$ \\
\hline No higher education & & $\begin{array}{c}-0.74^{* * *} \\
(0.24)\end{array}$ & $\begin{array}{l}-0.17^{* * *} \\
(0.05)\end{array}$ & & $\begin{array}{c}-0.55^{* *} \\
(0.24)\end{array}$ & $\begin{array}{c}-0.08^{* *} \\
(0.03)\end{array}$ \\
\hline Exit & & $\begin{array}{c}-0.03^{*} \\
(0.01)\end{array}$ & $\begin{array}{c}-0.005^{*} \\
(0.003)\end{array}$ & & $\begin{array}{c}-0.02 \\
(0.02)\end{array}$ & $\begin{array}{c}-0.003 \\
(0.002)\end{array}$ \\
\hline Intercept & $\begin{array}{c}0.22 \\
(0.14)\end{array}$ & $\begin{array}{c}0.39^{* *} \\
(0.20)\end{array}$ & $\begin{array}{r}0.07^{*} \\
(0.04)\end{array}$ & $\begin{array}{c}-0.95^{* * *} \\
(0.14)\end{array}$ & $\begin{array}{l}-0.89^{* * *} \\
(0.19)\end{array}$ & $\begin{array}{l}-0.13^{* * *} \\
(0.03)\end{array}$ \\
\hline AIC & 611.8 & 608.1 & - & 717.7 & 697 & - \\
\hline Observations & 538 & 538 & 538 & 725 & 725 & 725 \\
\hline
\end{tabular}

Note: Logistic regression models. Dependent variable-Public/private post-parliamentary positions. Robust standard errors are in parentheses. Continuous variables are centred around the mean; business-friendly party and ISEI are also standardized. Higher education is the reference category. AIC, Akaike information criterion; AME, average marginal effects (discrete percentage change for binary variables). ${ }^{*} \mathrm{p}<0.1$; $* * \mathrm{p}<0.05 ; * * \mathrm{p}<0.01$. 
post-parliamentary careers. On average, being female decreases the probability of public

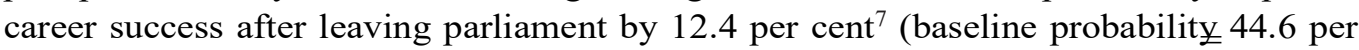
cent $^{8} ; \mathrm{p}<0.05$ ) and of private career success by 9.7 per cent (baseline probability 23.3 per cent; $\mathrm{p}<0.01$ ). When we split up our model into countries or introduce party dummies, this gender gap is still significantly present in Germany (see our models in Tables A8-A14 in the Online Appendix). Interestingly, the gender effect is higher in the public sector than in the private sector, where we could have expected a negative effect originating in an anti-female corporate culture. Possibly, attempts to diversify boards in recent years have resulted in better chances for women in business boards in contrast to public foundations.

Our second set of variables scrutinizes the importance of political achievement for postparliamentary employers. We see that - as $\mathrm{H} 2$ suggests - employers indeed, in general, appreciate political achievement. Two of three political achievement variables we tested ('cabinet', 'party position') show clear effects. In all our models we found a clear and robust effect of cabinet position on the likelihood of obtaining an attractive position after the legislative mandate. As model 2 displays, positions in the cabinet have a significant impact on the probability of obtaining a more attractive position in the public sector after parliament. The results in Table 1 show that, on average, being a member of the cabinet increases the probability of public career success by 29.8 per cent $(p<0.001)$. As for private post-parliamentary employment, being a member of the cabinet increases the probability of private career success by 24.5 per cent ( $p<0.001$ ). In comparison, having a position in the party increases the probability of private career success by 19.0 per cent $(p<0.01)$. In addition, being a member of the parliament presidium also has a significant positive effect on the probability of private career success. Therefore, achievement within the party or parliament is more important for private employers, whereas cabinet membership seems to serve as a stepping stone for both successful public and private careers. Hence, the second hypothesis is moderately confirmed, as political achievement in the cabinet, the political party and the parliament does matter for success, but does not matter equally in both public and private sectors.

When we consider H3, which concerns negative political achievement, we expect that those who suddenly lose their mandate or leave due to age are less prepared to find attractive employment. For all three variables, our analysis offers confirmation. The coefficients in model 2 (Table 1) are significant at the 1 per cent level and negative as expected. We can see that on average, failed re-nomination decreases the probability of attractive public sector employment by 38.0 per cent, whereas failed re-election decreases the same probability by 42.8 percent.

Where the effects of failed nomination and/or election were quite large for the public sector, the results are, though significant, less pronounced for the private sector. Failing to be elected decreases the probability of private career success by 12.1 per cent on average, while failing a nomination decreases the same probability by 13.1 per cent. Although the baseline probability is much lower for private careers, the effects are still significantly smaller in comparison to the public career success results.

As the last part of negative political achievement, increasing age also significantly decreases the probability of career success for both sectors. In the public sector, the average marginal effect for an additional year is -0.6 per cent $(\mathrm{p}<0.05)$. In the private sector, the average marginal effect for an additional year is -1.0 per cent $(p<0.001)$. These 
results therefore show that negative political achievement significantly reduces the chances of more attractive post-parliamentary employment and seem to confirm $\mathrm{H} 3$.

As for the control variables, the main control variable for pre-parliamentary occupational status, ISEI, is marginally significant for the public sector. On average, a standard deviation increase in ISEI score increases the probability of public career success by 3.4 per cent $(\mathrm{p}<0.1$ ). Additionally, we find that of the two party-level variables, only business-friendly party shows clear effects. Having mere access to the political party in power does not seem to increase the chances of attractive employment. As for business friendliness, this variable is not significant for the private sector, whereas it is significant according to conventional standards for the public sector. On a scale where a higher score means a freer and more liberal market approach, the probability that a parliamentarian will obtain a more attractive public sector position is on average 4.8 per cent $(\mathrm{p}<0.05)$ higher for a standard deviation increase on the business-friendly orientation scale of the parliamentarian's party. The probable explanation is that business friendliness is the only party-level variable that picks up important differences in party-level access to public political positions. ${ }^{9}$ This effect could signal that overall right-wing and liberal parties have tighter networks to foundations and boards in both private and public sectors, so that exparliamentarians from centre and centre-right parties have better chances of obtaining post-parliamentary positions. One example for the relevance of ideological orientation is Ingrid Matthäus-Meier, a rather liberal, business-friendly finance expert from the Social Democrats who became board member of a large public German bank after her mandate. She may also have benefited from her experience as head of the finance committee, as our findings for the business-committee variable highlight. Having been a member in a business-related committee has the expected and significant effect on the probability of career success in the private sector. On average, having been a member of a business committee increases the probability of private career success by 19.4 per cent $(p<0.01)$. This effect is only relevant for the private sector so that it is advisable to have two different models to detect this effect.

Aside from ideological orientation, the effect of pre-parliamentary political experience in terms of the length of party membership is significant for the private sector. Furthermore, the sheer number of years in parliament also adds to this experience effect for the private sector. For private sector career success, the average marginal effect of years as a parliamentarian is 0.7 per cent $(p<0.01)$ for each additional year. Furthermore, the general control variable on higher education shows the expected effects. Higher education is valued in both public and private sectors, but the effect is stronger for public sector positions. On average, not having higher education qualification decreases the probability of public career success by 17.4 per cent $(\mathrm{p}<0.001)$ and the probability of private career success by 8.1 per cent $(\mathrm{p}<0.01)$. Lastly, there are significant cohort effects for the public sector when taking into account the year of exit. For the private sector, cohort effects appear when using the alternative legislative period measure (see Table A13 in the Online Appendix).

Several robustness checks were run that can be found in the Online Appendix (Its tables are referred to here with prefix A). These models include party dummies (see Tables A9 and A12), and separately run models per country (see Tables A8 and A11). As for other robustness checks, we found that multicollinearity does not pose a significant problem as our independent variables do not highly correlate with one another, and the range 
of eigenvalues is small. We also found that the results hold under alternative education measures (such as having a doctorate) or changing the control for exit year to the legislative period in which a parliamentarian exited (see Tables A10 and A13). When individual models are run for each country (see Tables A8 and A11), the origins of the comparative results become clearer. Gender does not reach statistical significance in the models we ran for the Netherlands in the Online Appendix. Cabinet positions have a significant effect on career success in the Netherlands, but the same effects in Germany are only significant when party dummies are introduced (see Table A12 in the Online Appendix). Accordingly, general legislative experience plays a smaller role since the years as an MP do not seem to show any significance in the Netherlands.

\section{Discussion}

Our analysis demonstrates that gender differences in the attractiveness of postparliamentary employment exist and that they are profound. Male parliamentarians are found to be much more likely to obtain attractive positions than females after their mandate. This might provide evidence that both public and private sector jobs are distributed in a non-competitive market characterized by cronyism and discrimination against women. The exact reasons for how women with similar qualifications as men are less successful after a political career still need to be explored to find out to what degree a lack of networks, or a more general bias against women, are responsible for the employment imbalance in the informal job market for post-parliamentary employment. We know of several examples for situations where male-dominated networks prevented women from standing as directly nominated candidates because they were in competition with an established man with better networks. ${ }^{10}$ Hence, we assume that similar mechanisms may apply to the post-parliamentary job market. One confirmation of this explanation is the counter example of the previously cited Ingrid Matthäus-Meier and her postparliamentary success in the banking sector after her mandate, which also seems to be "due to her excellent networks within the Social-Democratic party". ${ }^{11}$ With regard to the relationship between gender and achievement, we importantly find that women are less likely to achieve attractive post-parliamentary employment in either sector, even when pre- and within-parliamentary achievement are statistically controlled for. This means that post-parliamentary employers are not simply re-producing inequalities that emerged beforehand, but seem in fact to be adding additional inequalities themselves.

Second, considering the factors that influence post-parliamentary career success in the public and private sectors, our theoretical framework also suggested political achievement as an explanation. We found that companies and public institutions both want to attract visible and well-known politicians, and do so by hiring politicians that have had prominent positions within a cabinet or a party (the latter only for companies). Generally, it seems, therefore, more important that parliamentarians mainly distinguish themselves in parliament instead of beforehand, as their occupational status (as measured by ISEI) is not a good predictor for post-parliamentary success. There seem to be slightly different pathways at work between the public and private post-parliamentary job market: when it comes to networks and access to political players, it appears that companies are 
predominantly interested in people who are well connected to business committees and party members outside of the cabinet.

This image is further strengthened when we look at negative political achievement, that is, failed re-nomination or re-election. Negative political achievement turned out to have both a very strong and highly significant effect. One reason for this finding might be a reputation loss on the one hand, since public employers might care whether they employ people who failed publicly. Furthermore, a parliamentarian who failed re-nomination from their party might have lost approval and therefore might have also lost considerable network capital. On the other hand, these politicians - in particular those who were not re-elected - had little time to prepare for their time after the mandate. Moreover, in the case of severe party losses, they might have to face competition on the post-parliamentary job market from other party colleagues. For example, when the German Liberal Democrats surprisingly failed to achieve the necessary 5 per cent threshold to enter parliament in the 2013 Bundestag election, a rather large group of FDP MPs were blindsided and thus unprepared for life thereafter. ${ }^{12}$

Our additional control variables also included business-related experience in parliamentary committees. The finding that experience in business committees increases the chances of attractive post-parliamentary private employment, does not alleviate fears about potential issues with problematic information flows and biased interest representation. Businesses not only have an interest in these committees but they also seem to give committee member politicians preferential treatment.

\section{Conclusion}

Current literature lacks information on post-parliamentary careers and the question of whether parliament is a stepping stone or stumbling block for the careers of men and women. The objective of this paper was to address and investigate a potential gender gap in post-parliamentary careers and the role of achievement/status within parliament, while providing three new tangible contributions: first, new systematic data from two countries, the Netherlands and Germany, second, the first cross-country systematic analysis of postparliamentary careers and third, the capacity to reduce unobserved variable bias by controlling for pre-parliamentary achievement. The results show that only a limited percentage of both male and female parliamentarians are able to use the parliament as a stepping stone for career advancement to higher, more lucrative and more attractive postparliamentary positions in both public and private sectors. The presented results highlight how achievement in parliament, both in a positive (high status parliamentary positions) and a negative sense (failed nomination and re-election) translates to attractive postparliamentary employment later. Furthermore, attractive employers in both public and private sectors greatly value achievement. Moreover, we document the presence of a persistent and substantial gender gap. This gap exists regardless of party, country or political position and persists even when the status of the pre-parliamentary profession and achievement within parliament are controlled for. The image that emerges is that elected office primarily serves as a stepping stone for men but can be a career stumbling block for women. If we assume that politicians make rational career decisions, the implication of this might be that aspirant female politicians could be more reluctant to run for elected office 
in the first place. The reluctance of post-parliamentary employers to hire women might, as such, indirectly be one of the reasons for the descriptive underrepresentation of women in parliament.

\section{Acknowledgements}

We would like to thank Max Würfel for sharing his data on German post-parliamentary positions with us, as well as our experts in the Netherlands and Germany who helped us coding the post-parliamentary positions. The article benefited from comments by participants at the Tel Aviv Workshop on Legislative Coalition Management in 2015, the ECPR General Conference in Prague 2016, ECPR Parliaments Conference in Munich 2016, and the University of Basel Political Science Colloquium as well as suggestions by Kaba Barsch, José Cheibub, Elena Frech, Jean-Francois Godbout, Oliver Huwyler, Shane Martin, Tim Mickler, Tamaki Ohmura, Björn-Erik Rasch, Ulrich Sieberer, Kaare Strøm, Jennifer vanHeerde-Hudson, Richard Whitaker, and David Willumsen.

\section{Online Appendix}

Additional supporting information may be found in the Online Appendix.

\section{Notes}

1. As in the case of Peer Steinbrück, German finance minister (2005-2009), who ended his political career prematurely to start a career in a bank.

2. As a result, 62 cases were removed from our sample. This decision probably biases our sample slightly towards those that found attractive post-parliamentary employment. This however, does not hurt the internal validity of our results, as our hypotheses are all relational and there is no structured bias to be expected on the independent variable side.

3. The literature makes a distinction between two types of career success: subjective and objective career success (Heslin, 2005; Ng et al., 2005). Subjective career success relates to job satisfaction, or the way in which a person perceives his own career. Objective career success consists mainly of occupational status and salary, and is coded here as either less/equally_(0) or more attractive (1) than being a parliamentarian.

4. In the Netherlands the post-parliamentary coding included cabinet positions. Even though Dutch cabinet members are not members of the parliament, here they are treated as such. The rationale is that this selected government office is very close to the parliamentary career. Furthermore, because ministers and state secretaries do take a seat in the Bundestag, the Dutch cabinet members here are treated as parliamentarians with a special political position.

5. The inclusion of ISEI means a slight reduction ( $\mathrm{n} \underline{\underline{87}})$ in cases for which this measure is unobtainable.

6. This information turned out to be impossible to obtain for 29 per cent of the parliamentarians in our dataset. For those cases, we decided to take the number of years from the first political position until entry into parliament.

7. This is the average marginal effect, that is, the average probability of success for females in the public sector is 32.4 per cent (baseline probability average marginal effect).

8. See the descriptive analysis for the source of these probabilities.

9. When introducing party dummies into the model, this variable becomes insignificant (see Tables A9 and A12 in the Online Appendix). 
10. As in the case of Barbara Stamm (http:/www.handelsblatt.com/politik/deutschland/bundestagswahl/ alleschlagzeilen/unter-maennern-der-skandal-als-chance/20183870-2.html [accessed 11 November 2017]) or Iris Ripsam (http://www.spiegel.de/spiegel/gleichberechtigung-politikerinnen-fordern-einewahlrechtsaenderung-a-1164973.html [accessed 11 November 2017]).

11. See https://www.handelsblatt.com/finanzen/banken-versicherungen/kfw-chefin-ingrid-matthaeus-mai er-juristin-auf-verlorenem-posten-seite-2/2943802-2.html [accessed 18 May 2019].

12. See http://www.stuttgarter-zeitung.de/inhalt.ex-abgeordnete-aus-baden-wuerttemberg-neustart-ins-leb ennach-dem-bundestag.b0407cd3-aeaf-400c-a4d3-ef7116894da8.html [accessed 21 October2019].

\section{References}

Anderson, L. (2010). The ex-presidents. Journal of Democracy 21: 64-78.

Baturo, A. \& Arlow, J. (2017). Is there a 'revolving door' to the private sector in Irish politics? Irish Political Studies 33: 1-26.

Baturo, A. \& Mikhaylov, S. (2016). Blair disease? Business careers of the former democratic heads of state and government. Public Choice 166:335-354.

Bertrand, M., Bombardini, M. \& Trebbi, F. (2011). Is it whom you know or what you know? An empirical assessment of the lobbying process. Cambridge, MA: National Bureau of Economic Research.

Borchert, J. \& Stolz, K. (2003). Die Bekämpfung der Unsicherheit: Politikerkarrieren und Karrierepolitik in der Bundesrepublik Deutschland. Politische Vierteljahresschrift 44:148-173.

Borchert, J. \& Stolz, K. (2011). Introduction: Political careers in multi-level systems. Regional \& Federal Studies 21:107-115.

Branson, D.M. (2006). No seat at the table: How corporate governance and law keep women out of the boardroom. New York: NYU Press.

Byrne, C. \& Theakston, K. (2016). Leaving the House: The experience of former members of parliament who left the house of commons in 2010. Parliamentary Affair 69: 686-707.

Childs, S. (2013). Intra-party democracy: A gendered critique and a feminist agenda. In W. Cross \& R.S. Katz (eds), The challenges of intra-party democracy. Oxford: Oxford University Press.

Claessen, C. (2015). Political careers and the Tweede Kamer: Parliamentarians 'pathways to parliament and career success after representative life. Zurich: ETHZurich.

Claveria, S. \& Verge, T. (2015). Post-ministerial occupation in advanced industrial democracies: Ambition, individual resources and institutional opportunity structures. European Journal of Political Research 54: 819-835.

Croson, R. \& Gneezy, U. (2009). Gender differences in preferences. Journal of Economic Literature 47: 448-474.

Crowder-Meyer, M. (2013). Gendered recruitment without trying: How local party recruiters affect women's representation. Politics \& Gender 9: 390-413.

Davidson-Schmich, L.K. (2015). A glass half full: Gender quotas and political recruitment. Ann Arbor, MI: University of Michigan Press.

Davies, L. (2011). Women on boards. Available online at: https://assets.publishing.service.gov.uk/gove rnment/uploads/system/uploads/attachment_data/file/31480/11-745-women-on-boards.pdf

Devillard, S., Sancier-Sultan, S. \& Werner, C.J.M.Q. (2014). Why gender diversity at the top remains a challenge. McKinsey Quarterly 2: 23-25.

Diermeier, D., Keane, M. \& Merlo, A. (2005). A political economy model of congressional careers. American Economic Review 95: 347-373.

Eggers, A.C. (2010). The Partisan Revolving Door. Working Paper. Cambridge, MA: University ofHarvard.

Eggers, A.C. \& Hainmüller, J. (2009). MPs for sale? Returns to office in postwar British politics. American Political Science Review 103: 513-533.

Ely, R. \& Padavic, I. (2007). A feminist analysis of organizational research on sex differences. Academy of Management Review 32: 1121-1143.

Escobar-Lemmon, M. \& Taylor-Robinson, M.M. (2009). Getting to the top: Career paths of women in Latin American cabinets. Political Research Quarterly 62: 685-699. 
Estevez-Abe, M. (2006). Gendering the varieties of capitalism. A study of occupational segregation by sex in advanced industrial societies. World Politics 59: 142-175.

Fish, M.S. \& Kroenig, M. (2009). The handbook of national legislatures: A global survey. New York: University Press Nueva York.

Fox, R.L. \& Lawless, J.L. (2004). Entering the arena? Gender and the decision to run for office. American Journal of Political Science 48:264-280.

Fox, R.L. \& Lawless, J.L. (2014). Uncovering the origins of the gender gap in political ambition. American Political Science Review 108: 499-519.

Frantzich, S.E. (1978). De-recruitment: The other side of the congressional equation. Political Research Quarterly, 31:105-126.

Freund, D. \& Bendel, Y. (2016). Access All areas: When EU politicians become lobbyists. Transparency International EU. Available online at: http://www.transparency.eu/.

Gains, C. \& Annesley, F. (2010). The core executive: Gender, power and change. Political Studies 58: 909929.

Ganzeboom, H.B.G., De Graaf, P.M. \& Treiman, D.J. (1992). A standard International Socio-Economic Index of occupational status. Social Science Research 21:1-56.

Glass, C. \& Cook, A. (2016). Leading at the top: Understanding women's challenges above the glass ceiling. Leadership Quarterly 27: 51-63.

Goldman, E., Rocholl, J. \& So, J. (2009). Do politically connected boards affect firm value? Review of Financial Studies 22: 2331-2360.

Hall, P.A. \& Soskice, D. (2001). Varieties of capitalism: The institutional foundations of comparative advantage. Oxford: Oxford University Press.

Heslin, P.A. (2005). Conceptualizing and evaluating career success. Journal of Organizational Behaviour 26: 113-136.

Hudon, R. \& Yates, S. (2016). Revolving door: A management approach based on effectiveness or a democratic assessment concerned about the balance of power. Prague: ECPR General Conference.

Jaffé, M.E., Rudert, S.C. \& Greifeneder, R. (2019). You should go for diversity, but I'd rather stay with similar others: Social distance modulates the preference for diversity. Journal of Experimental Social Psychology 85. https://doi.org/10.1016/j.jesp.2019.103881

Jalalzai, F. \& Krook, M.L. (2010). Beyond Hillary and Benazir: Women's political leadership worldwide. International Political Science Review 31: 5-21.

Kanthak, K. \& Woon, J. (2014). Women don't run? Election aversion and candidate entry. American Journal of Political Science. https://doi.org/10.1111/ajps.12158

Kopecký, P., Mair, P. \& Spirova, M. (2012). Party patronage and party government in European democracies. Oxford: Oxford University Press.

Lawless, J.L. \& Fox, R.L. (2005). It takes a candidate: Why women don't run for office. Cambridge: Cambridge University Press.

Lazarus, J., McKay, A. \& Herbel, L. (2016). Who walks through the revolving door? Examining the lobbying activity of former members of Congress. Interest Groups \& Advocacy 5:82-100.

Lovenduski, J. (1986). Women and European politics: Contemporary feminism and public policy. Amherst, MA: University of Massachusetts Press.

Luechinger, S. \& Moser, C. (2014). The value of the revolving door: Political appointees and the stock market. Journal of Public Economics 119: 93-107.

Lyness, K.S. \& Thompson, D.E. (2000). Climbing the corporate ladder: Do female and male executives follow the same route? Journal of Applied Psychology 85: 86-101.

Marsh, M. (1993). Selecting party leaders in the Republic of Ireland. European Journal of Political Research 24: 295-316.

Mian, A.R. \& Khwaja, A.I. (2004). Do lenders favor politically connected firms? Rent provision in an emerging financial market. Quarterly Journal of Economics 120: 1371-1411.

Ng, T.W.H., Eby, L.T., Sorensen, K.L. \& Feldman, D.C. (2005). Predictors of objective and subjective career success: A meta-analysis. Personnel Psychology 58: 367-408.

Norris, P. \& Lovenduski, J. (1995). Political recruitment-Gender, race and class in the British parliament. Cambridge: University of Cambridge. 
Palmer, M. \& Schneer, B. (2016). Capitol gains: The returns to elected office from corporate board directorships. Journal of Politics 78: 181-196.

Preece, J. \& Stoddard, O. (2015). Why women don't run: Experimental evidence on gender differences in political competition aversion. Journal of Economic Behavior \& Organization 117: 296-308.

Raymond, C.D., Yildirim, M.T. \& Overby, M.L. (2016). Calling it Quits: Legislative Retirement in Comparative Perspective. In 3rd General Conference of the ECPR Standing Group on Parliaments, Munich.

Rhode, D.L. \& Packel, A.K. (2014). Diversity on corporate boards: How much difference does difference make. Delaware Journal of Corporate Law 39: 377-426.

Ryan, M.K. \& Haslam, S.A. (2007). The glass cliff: Exploring the dynamics surrounding the appointment of women to precarious leadership positions. Academy Of Management Review 32: 549-572.

Schneider, M.C., Holman, M.R., Diekman, A.B. \& McAndrew, T. (2016). Power, conflict, and community: How gendered views of political power influence women's political ambition. Political Psychology 37: 515-531.

Secker, W.P. (1995). Personal circulation in the Dutch second chamber 1888-1993: Towards institutionalization and professionalization and then? Historical Social Research 20: 3-32.

Strøm, K. (1993). Competition ruins the good life. European Journal of Political Research 24: 317-347.

Theakston, K. (2007). Life after losing or leaving: The experience of former members of parliament. A Report for the Association of Former Members of Parliament by the University of Leeds. The Association of Former Members of Parliament.

Theakston, K. (2012). Life after political death: Former leaders in western democracies. Representation 48: 139-149.

Theriault, S.M. (1998). Moving up or moving out: Career ceilings and congressional retirement. Legislative Studies Quarterly 23: 419-433.

Vaubel, R., Klingen, B. \& Müller, D. (2012). There is life after the commission: An empirical analysis of private interest representation by former EU-commissioners, 1981-2009. Review of International Organizations 7: 59-80.

Verge, T. \& Claveria, S. (2016). Gendered political resources: The case of party office. Party Politics. https://doi.org/10.1177/1354068816663040

Vidal, J.B.I., Draca, M. \& Fons-Rosen, C. (2012). Revolving door lobbyists. American Economic Review 102: 3731-3748.

Wägnerud, L. (2009). Women in parliaments: Descriptive and substantive representation. Annual Review of Political Science 12: 51-69.

Würfel, M. (2014). Life after the Bundestag: A quantitative analysis of the post-parliamentary careers of former German MPs. Zurich: ETH Zurich.

Würfel, M. (2017). Life after the Bundestag: An analysis of the postparliamentary careers of German MPs. German Politics. https://doi.org/10.1080/09644008.2017.1344642.

Address for correspondence: Stefanie Bailer, Department of Political Science, University of Basel. Email: stefanie.bailer@unibas.ch 


\section{Online Appendix}

\section{The Winners of Legislative Mandate}

An analysis of post-parliamentary career positions in Germany and the Netherlands

Clint Claessen, Stefanie Bailer and Tomas Turner-Zwinkels 
This appendix consists of three components. First, there is a general guideline for the coding of the attractiveness of post-parliamentary positions. Here we look at the intercoder reliability, the operationalization and some detailed instructions concerning specific career positions. Second, there is a general overview of all the variables that the dataset for this paper consists of. Third and last, various robustness checks are presented as additional models to address potential caveats.

The three components:

1. General Coding Guideline

2. Variable Overview of the Political Careers Dataset

3. Robustness Checks in various Models and Tables 


\title{
General Coding Guideline for post-parliamentary positions
}

\author{
(Dutch Parliament: 1983-2015) \\ (German Parliament: 1997-2009)
}

What follows are the coding guidelines for the datasets on post-parliamentary positions in the Dutch Tweede Kamer and the German Bundestag. Our 6 coders (three from the Netherlands, three from Germany) were first shown a list of more attractive positions and the subsequent coding rules. They could accept these pre-coded positions and guidelines or amend them. Next, they coded a random sample of cases and a separate set of critical cases (around 40). On the basis of the random samples the intercoder-reliability was measured (Table A1). In this codebook, the coding table, general coding guidelines and some critical cases are presented.

Table A1. Intercoder Reliability of the Career Success Measure

\begin{tabular}{|l||l||l|}
\hline Country & Coder & Percentage Agreement \\
\hline \hline NL & 1 & $93 \%$ \\
\hline NL & 2 & $87 \%$ \\
NL & 3 & $87 \%$ \\
\hline DE & 4 & $85 \%$ \\
\hline DE & 5 & $75 \%$ \\
DE & 6 & $87 \%$ \\
\hline
\end{tabular}

The coding tables that were sent to the coders looked like this (Table 2):

Legend:

ID\#(Case number)

Dat. (Date of birth)

(Names are left out to increase objectivity)

Code $(2=$ More attractive, $1=$ Equally attractive, $0=$ Less attractive $)$

Table A2.

\begin{tabular}{|c|c|c|c|c|c|}
\hline ID\# & Dat. & Main occupation (within five years) & $\begin{array}{l}\text { Code } \\
\text { Public }\end{array}$ & $\begin{array}{l}\text { Code } \\
\text { Private }\end{array}$ & Reasoning \\
\hline 2292 & 1960 & $\begin{array}{l}\text { Alderman of Eindhoven (Salary }+-€ \\
8.113,34 \text { per month before taxes } \\
\text { excl. benefits) }\end{array}$ & 2 & & $\begin{array}{l}\text { Alderman of a large } \\
\text { city with a higher } \\
\text { salary }\end{array}$ \\
\hline
\end{tabular}

The following coding guidelines were sent to the coders: 


\section{Coding Guidelines}

This dataset contains post-parliamentary careers. A post-parliamentary career is operationalized as the highest paid/most prestigious occupational (public or private) position that a politician has earned within five years of leaving parliament (it is for the coder to decide which position that is and whether that position is more attractive, equally or less attractive).

\section{Salary guideline:}

Dutch parliamentarians are directly chosen representatives. Their salary is $€ 7311,56$ per month (before taxes). When additional benefits are included, the total income in 2012 for a parliamentarian was $€ 102.040,13$ (before taxes). This salary does not include bonuses for parliamentary positions, such as leader of the political fraction (between $+1 \%$ and $+11 \%$ ), chairman of the chamber $(+34 \%)$, vice-chairman (between $+1 \%$ and $3,5 \%)$. This salary does also not include the so-called party tax, which differs from party to party (on average $-10 \%$, $40 \%$ for the SP and $0 \%$ for the VVD). When corrected for purchasing power, this salary is more or less stable for the last 30 years.

In comparison, German parliamentarians earn a salary of $9.082 €$ per month (as of 01.01.2015) with $4.267 €$ tax-exempt.

\section{Attractiveness of Frequently Held Positions}

Aside from coding minister and state secretary as more attractive public positions, there are some other positions that are frequently held and coded in advance. In Germany, where there is no public information on salaries, a good indication for the attractiveness of public offices is whether there are members of the Bundestag (MdBs) in the sample who vacated their mandate for the public office in question. In consequence, public office positions in the executive at the state or federal level as well as senior mayoralties are coded as more attractive than the mandate. 
What follows is a list of these positions with their coding and the rational for the coding.

Table A3. Positions coded in advance (Germany)

\begin{tabular}{|c|c|c|}
\hline Position & Code & Rational \\
\hline $\begin{array}{r}\text { Senior Mayor } \\
\text { (Oberbürgermeister) }\end{array}$ & $2 / 1$ & $\begin{array}{l}\text { A mayor with a higher or equal salary ( }=>€ 7311,56 \text { before taxes) is } \\
\text { more attractive, as the crown appoints him. A mayor with lower } \\
\text { salary is equally attractive. (Their salary is determined by the number } \\
\text { of inhabitants in their muncipality) } \\
\text { More attractive because the salary is equal or higher and there is } \\
\text { more scope for influence. }\end{array}$ \\
\hline Alderman & $2 / 1 / 0$ & $\begin{array}{l}\text { An Alderman with a higher salary is more attractive }(>€ 7311,56 \\
\text { before taxes), as this position combines a public office with more } \\
\text { income. Therefore, an equal salary is equally attractive and a lower } \\
\text { salary is less attractive. (Salary is determined by the number of } \\
\text { inhabitants in the municipality) }\end{array}$ \\
\hline $\begin{array}{r}\text { City councilor } \\
\text { Local } \\
\text { Parliament/Executive }\end{array}$ & 0 & $\begin{array}{l}\text { A seat in a city council is less attractive, while it is a local position } \\
\text { with less salary. } \\
\text { Lower salary, more scope for influence but only local impact. }\end{array}$ \\
\hline Provincial Executive & 2 & $\begin{array}{l}\text { A seat in the provincial executive is more attractive, as the salary is } \\
\text { higher } € 7.899,67 \text { (bt.) and the executive function includes more } \\
\text { influence. } \\
\text { More attractive because the salary is equal or higher and there is } \\
\text { more scope for influence. }\end{array}$ \\
\hline $\begin{array}{r}\text { Provincial Parliament/ } \\
\text { State Parliament }\end{array}$ & 0 & $\begin{array}{l}\text { A seat in the provincial parliament is less attractive, as it is (often) } \\
\text { part-time, earns a lower salary and is on a lower organizational level. }\end{array}$ \\
\hline First Chamber & 1 & $\begin{array}{l}\text { The first chamber membership counts as equally attractive, as it is a } \\
\text { more 'honorable' position, but not full-time and with a lower salary. } \\
\text { Additionally, this position is more often occupied by people with a } \\
\text { certain status and expertise. }\end{array}$ \\
\hline King's Commissioner & 2 & $\begin{array}{l}\text { This position is more attractive, while both salary ( } € 144.500 \text { per } \\
\text { year) and status (appointed by the crown) are higher. }\end{array}$ \\
\hline $\begin{array}{r}\text { Dijkgraaf } \\
\text { (chair of a Dutch } \\
\text { water board) }\end{array}$ & 2 & $\begin{array}{l}\text { More attractive, as this historically important position is appointed by } \\
\text { the crown accompanied by a higher salary (max. } € 8.514,18 \text { per } \\
\text { month (Waterschapsbesluit)). }\end{array}$ \\
\hline Council of State & 2 & $\begin{array}{l}\text { As one of the oldest governmental organizations in the world (1531), } \\
\text { the council of state offers more attractive positions in terms of } \\
\text { occupational status (appointed by the crown). }\end{array}$ \\
\hline $\begin{array}{r}\text { Social-Economic } \\
\text { Council (Appointed } \\
\text { European Consbiymtheorowndrath } \\
(\text { SER)(Kroonleden) }\end{array}$ & 2 & $\begin{array}{l}\text { A more attractive position, as some members are appointed by the } \\
\text { crown and membership involves a higher public status. }\end{array}$ \\
\hline Minister & 2 & More attractive \\
\hline State secretary & 2 & More attractive \\
\hline Council of Europe & $2 / 2$ & More attractive (International position with higher salary) \\
\hline $\begin{array}{r}\text { Other international } \\
\text { positions }\end{array}$ & $2 / 2$ & $\begin{array}{l}\text { Positions at intergovernmental organizations such as the World Bank, } \\
\text { the IMF, the UN, NATO, the European Commission etc. (positions }\end{array}$ \\
\hline
\end{tabular}




\begin{tabular}{|r|l|l|}
\hline & & $\begin{array}{l}\text { with a high international status) (in case of doubt: provide reasoning } \\
\text { for different coding) }\end{array}$ \\
\hline Minister of State & 2 & $\begin{array}{l}\text { A honorary title, that is given for exceptional merit to former MPs or } \\
\text { ministers. }\end{array}$ \\
\hline European Parliament & $1 / 1$ & $\begin{array}{l}\text { Salary level is more or less equal, with a similar amount of influence } \\
\text { (depending on the position and the party fraction). }\end{array}$ \\
\hline $\begin{array}{r}\text { Federal/State } \\
\text { Commissioners } \\
\text { (Beauftragte) }\end{array}$ & 2 & $\begin{array}{l}\text { More attractive because the salary is assumed to be more or less } \\
\text { equal and there is more scope for influence in the specific domain. }\end{array}$ \\
\hline
\end{tabular}

\section{Other coding rules:}

Politicians can only have one (more attractive) position at the same time. This position is either public or private (in case of more positions at the same time: the most attractive position is decisive).

Public and private

For the coder to decide (in general: semi-public $=$ public)

Retirement is coded as a less attractive private position. The assumption is that attractive job offers are never declined for reasons of retirement.

Consultancy jobs are coded as a more attractive private sector position if it is a senior position in an international consultancy or a position in the executive board of a consultancy which is active nationwide (indicator: company HQ in Berlin). The assumption is that these jobs are better paid than the mandate.

Otherwise, consultancy jobs are coded as less attractive.

Positions in the lobbying industry are coded as more attractive if it is a senior position in an internationally or nationally active syndicate or company. The assumption is that these jobs are better paid than the mandate.

Otherwise lobbying positions are coded as less attractive.

The positions of attorneys and judges are coded in general as equally attractive as the mandate because of the overall high income but lesser opportunities of influence. Exceptions are the judgeship and attorneyship of international courts and high federal courts which are coded as more attractive.

Senior positions in multinational companies and memberships in executive/supervisory boards of nationally active companies are coded as more attractive private sector positions.

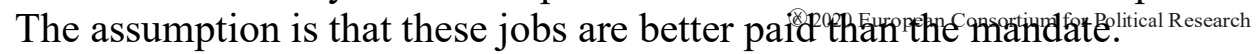




\section{Examples of Critical Cases (Dutch Tweede Kamer)}

\begin{tabular}{|c|c|c|}
\hline ID\# & $\begin{array}{l}\text { Date } \\
\text { of } \\
\text { Birth }\end{array}$ & Positions (Within five years) \\
\hline 2208 & 1964 & $\begin{array}{l}\text { Chairman CNV Education, from January 1st, } 2005 \text { until Mai 1st } 2008 \text { (Information: } \\
\text { https://www.cnvo.nl/fileadmin/user_upload/PDF/profiel_Member_db_2011.pdf) }\end{array}$ \\
\hline 1845 & 1953 & Interim-manager and consultant "BGA Beleidsrendement" in The Hague, from 2002 until 2004 \\
\hline 2636 & 1940 & $\begin{array}{l}\text { Chairman TICA (Temporary Institute for Coordination and Compatibility), from } 1995 \text { until } 1997 \text { \& Chairman } \\
\text { National Institute Social Insurances (LISV), from } 1997 \text { until } 2002\end{array}$ \\
\hline 2460 & 1961 & Head Responsible Trading and Shareholders "MN Services", From April 1, 2007 \\
\hline 2407 & 1962 & Director Party Office PvdA \\
\hline 3228 & 1973 & Director Open State Foundation \\
\hline 2515 & 1948 & Director LBR (National Office against Race Discrimination) \\
\hline 2883 & 1940 & $\begin{array}{l}\text { Agricultural Board in Budapest (Working area: Hungary, Croatia, Yugoslavia, Bosnia-Hercegovina and } \\
\text { Macedonia), from June } 1998 \text { until } 2005\end{array}$ \\
\hline 2856 & 1949 & Director Social Affairs Employment-Services in the Nijmegen region, from 1989 until 1994 \\
\hline 2754 & 1982 & $\begin{array}{l}\text { Chairman RTV Rijnmond, from December } 1997 \text { until December } 2003 \text { \& Member of the City Council of } \\
\text { Rotterdam, from } 14 \text { April, } 1998 \text { until } 14 \text { March, } 2002\end{array}$ \\
\hline 2735 & 1947 & $\begin{array}{l}\text { Advisor Rijksgebouwendienst, from } 1 \text { June } 1990 \text { \& Member Provincial Council of Limburg, from } 12 \text { April, } 1994 \\
\text { until } 2002\end{array}$ \\
\hline 2634 & 1940 & $\begin{array}{l}\text { Chairman Kamer van Koophandel and Fabrieken for The Hague (from 1 January, } 1996 \text { in the Haaglanden), from } 1 \\
\text { January, } 1992 \text { until } 1 \text { January, } 2002 \\
\text { Side Jobs: } \\
\text { - -Member of Supervisory Board N.V. Databank in Woerden, from } 1995 \text { until } 1999 \\
\text { - -Member of Supervisory Board "Raptim", Tilburg/Genève, from } 1995 \text { until } 2007 \\
\text { - -Member of Supervisory Board Pecchiney Nederland (later Alcan) te Vlissingen, from } 1996 \text { until } 2006 \\
\text { - - Member of Supervisory Board "Overlaat Beheer" B.V. in Drunen, from } 1997 \text { until } 2002 \\
\text { - -Chairman Holland Fish }\end{array}$ \\
\hline
\end{tabular}




\begin{tabular}{|c|c|c|}
\hline & & $\begin{array}{ll}\text { - } & \text {-Advisor Nethconsult } \\
\text { - } & \text {-Chairman Sitproneth } \\
\text { - } & \text {-Member of Board of Directors Royal Dutch Association for Physiotherapy } \\
\end{array}$ \\
\hline 2422 & 1976 & Technical Director in Dar-es-Salaam (Tanzania) for the NGO PharmAccess, from September 2013 \\
\hline 3153 & 1969 & General Director ISM (Innovative Solutions in Media) eCompany in Rotterdam, from October 2010 \\
\hline 2226 & 1967 & Director Dutch Side-Effects Center "Lareb" in 's-Hertogenbosch, from 1 April, 2013 \\
\hline 2560 & 1949 & Chairman Association of Waste Companies, from 1 July, 2004 until 2007 \\
\hline 3184 & 1964 & $\begin{array}{l}\text { Manager of the Regional Information and Expert Center (RIEC) for the administrative approach to organized crime } \\
\text { in South-West Brabant }\end{array}$ \\
\hline
\end{tabular}




\section{Variable List of the Political Careers Dataset}

This document contains a list of the variables in the comparative political careers dataset. It also includes a description of the exact coding of the variables that are derived from the Manifesto Project.

Table A4. Variable List

\begin{tabular}{|c|c|c|c|c|}
\hline No. & Type & Description & Measure & Comment \\
\hline 1. & Dependent Variable & $\begin{array}{l}\text { Attractiveness } \\
\text { Public/Private } \\
\text { Position }\end{array}$ & $0-1$ & $\begin{array}{l}\text { Description of coding see } \\
\text { above }\end{array}$ \\
\hline 2. & $\begin{array}{l}\text { Independent } \\
\text { Variable } \\
\text { Gender }\end{array}$ & Gender & $0-1$ & \\
\hline 3. & $\begin{array}{l}\text { Independent } \\
\text { Variables Political }\end{array}$ & $\begin{array}{l}\text { Cabinet } \\
\text { Member }\end{array}$ & $0-1$ & $\begin{array}{l}\text { Minister or state secretary in } \\
\text { the last period. }\end{array}$ \\
\hline 4. & achievement & Party Position & $0-1$ & $\begin{array}{l}\text { Party presidium, party } \\
\text { Executive in the last period }\end{array}$ \\
\hline 5. & & $\begin{array}{l}\text { Parliamentary } \\
\text { position }\end{array}$ & $0-1$ & $\begin{array}{l}\text { Presidium of the parliament in } \\
\text { the last period }\end{array}$ \\
\hline 6. & \begin{tabular}{l}
\multicolumn{2}{l}{ Independent } \\
Variables Negative \\
Political
\end{tabular} & $\begin{array}{l}\text { Failed } \\
\text { Reelection }\end{array}$ & $\overline{0-1}$ & $\begin{array}{l}\text { If expected election failed } \\
\text { as based on reports in the } \\
\text { media }\end{array}$ \\
\hline 7. & achievement & $\begin{array}{l}\text { Failed } \\
\text { Nomination }\end{array}$ & $0-1$ & $\begin{array}{l}\text { If placed on an on electable } \\
\text { position } \\
\text { as based on reports in the } \\
\text { media }\end{array}$ \\
\hline 8. & & Age at Exit & continuous & Control for retirement \\
\hline
\end{tabular}




\begin{tabular}{|c|c|c|c|c|}
\hline 9. & Control Variables & $\begin{array}{l}\text { Business } \\
\text { Friendly Party }\end{array}$ & Index & $\begin{array}{l}\text { Free market orientation } \\
(\text { Per401) from the Party } \\
\text { Manifesto Project }\end{array}$ \\
\hline 10. & & Party in Power & $0-1$ & $\begin{array}{l}\text { Whether the party is in power } \\
\text { at the time of leaving }\end{array}$ \\
\hline 11. & & $\begin{array}{l}\text { Business } \\
\text { Committee }\end{array}$ & $0-1$ & $\begin{array}{l}\text { Being a member of a Finance } \\
\text { or Business Committee in the } \\
\text { two last legislative periods } \\
\text { before leaving }\end{array}$ \\
\hline 12. & & Years as a MP & continuous & Number of years in parliament \\
\hline 13. & & $\begin{array}{l}\text { Party } \\
\text { membership }\end{array}$ & continious & $\begin{array}{l}\text { Number of years as a member } \\
\text { of their political party } \\
\text { (predecessors are also counted } \\
\text { as such) or, alternatively } \\
\text { number of years since first } \\
\text { party position }\end{array}$ \\
\hline 14. & & $\begin{array}{l}\text { Higher } \\
\text { Education }\end{array}$ & $0-1$ & University education (yes/no) \\
\hline 15. & & Exit & continuous & To control for period \\
\hline 16. & & $\begin{array}{l}\text { Legislative } \\
\text { Terms }\end{array}$ & nominal & $\begin{array}{l}\text { By cabinet in office; } \\
\text { alternative period control }\end{array}$ \\
\hline 17. & & ISEI & Index & $\begin{array}{l}\text { International Socio-Economic } \\
\text { Index of Occupational Status }\end{array}$ \\
\hline
\end{tabular}




\section{Manifesto Coding:}

*the number of (quasi-) sentences in each category is standardised taking the total number of (quasi-) sentences in the respective documents as a base

\section{Per401, Free Market Economy:}

Favourable mentions of the free market and free market capitalism as an economic model. May include favourable references to:

- Laissez-faire economy;

- Superiority of individual enterprise over state and control systems;

- Private property rights;

- Personal enterprise and initiative;

- Need for unhampered individual enterprises. 


\section{Additional Models and Tables}

A8-A10. The Netherlands

A8. General

A9. Political Party

A10. Alternative Period

A11-13. Germany

A11. General

A12. Political Party

A13. Alternative Period

A14. Limited Sample (1998-2015) 


\section{Netherlands}


Table A8. Logistic Regression Models of Post-Parliamentary Career Success in the Netherlands

\begin{tabular}{|c|c|c|c|c|c|c|}
\hline & $\begin{array}{l}\text { Public } \\
\text { Model } 5\end{array}$ & $\begin{array}{l}\text { Public } \\
\text { Model } 6\end{array}$ & $\begin{array}{l}\text { Public } \\
\text { (AME) }\end{array}$ & $\begin{array}{l}\text { Private } \\
\text { Model } 7\end{array}$ & $\begin{array}{l}\text { Private } \\
\text { Model } 8\end{array}$ & $\begin{array}{l}\text { Private } \\
\text { (AME) }\end{array}$ \\
\hline \multirow[t]{2}{*}{ GenderFemale } & -0.43 & -0.42 & -0.10 & -0.41 & -0.32 & -0.06 \\
\hline & $(0.30)$ & $(0.32)$ & $(0.08)$ & $(0.35)$ & $(0.35)$ & $(0.07)$ \\
\hline \multirow[t]{2}{*}{ Cabinet } & $1.92 * * *$ & $1.99 * * *$ & $0.39 * * *$ & $2.15 * * *$ & $2.03 * * *$ & $0.46^{* * *}$ \\
\hline & $(0.57)$ & $(0.60)$ & $(0.07)$ & $(0.44)$ & $(0.48)$ & $(0.10)$ \\
\hline \multirow[t]{2}{*}{ Party Position } & -0.66 & -0.45 & -0.11 & $1.23 * *$ & $1.54 * * *$ & $0.36^{* *}$ \\
\hline & $(0.50)$ & $(0.51)$ & $(0.14)$ & $(0.53)$ & $(0.59)$ & $(0.14)$ \\
\hline \multirow[t]{2}{*}{ Parliament Presidium } & 0.34 & 0.44 & 0.11 & $1.30 * *$ & $1.59 * *$ & $0.37 * *$ \\
\hline & $(0.48)$ & $(0.52)$ & $(0.11)$ & $(0.64)$ & $(0.72)$ & $(0.16)$ \\
\hline \multirow[t]{2}{*}{ Failed Election } & $-2.40 * * *$ & $-2.23 * * *$ & $-0.46^{* * *}$ & -0.86 & -0.93 & $-0.15^{* *}$ \\
\hline & $(0.64)$ & $(0.68)$ & $(0.08)$ & $(0.55)$ & $(0.57)$ & $(0.07)$ \\
\hline \multirow[t]{2}{*}{ Failed Nomination } & $-2.62 * *$ & $-2.47 * *$ & $-0.47 * * *$ & -1.03 & -1.30 & $-0.19 * *$ \\
\hline & $(1.09)$ & $(1.06)$ & $(0.10)$ & $(0.83)$ & $(0.90)$ & $(0.08)$ \\
\hline \multirow[t]{2}{*}{ Age At Exit } & -0.03 & -0.03 & -0.005 & $-0.06 * * *$ & $-0.08 * * *$ & $-0.01 * * *$ \\
\hline & $(0.02)$ & $(0.02)$ & $(0.004)$ & $(0.02)$ & $(0.02)$ & $(0.004)$ \\
\hline \multirow[t]{2}{*}{ ISEI } & $0.23^{*}$ & 0.17 & 0.03 & 0.15 & 0.02 & 0.004 \\
\hline & $(0.12)$ & $(0.14)$ & $(0.03)$ & $(0.16)$ & $(0.19)$ & $(0.03)$ \\
\hline \multirow[t]{2}{*}{ Business Friendly Party } & & 0.23 & 0.04 & & $0.30 *$ & $0.05^{*}$ \\
\hline & & $(0.17)$ & $(0.03)$ & & $(0.18)$ & $(0.03)$ \\
\hline \multirow[t]{2}{*}{ Party Not in Power } & & -0.11 & -0.03 & & -0.25 & -0.05 \\
\hline & & $(0.29)$ & $(0.07)$ & & $(0.37)$ & $(0.07)$ \\
\hline \multirow[t]{2}{*}{ Business Committee } & & 0.71 & $0.17^{*}$ & & 0.40 & 0.08 \\
\hline & & $(0.46)$ & $(0.10)$ & & $(0.58)$ & $(0.13)$ \\
\hline \multirow[t]{2}{*}{ Years as a MP } & & 0.02 & 0.004 & & -0.02 & -0.003 \\
\hline & & $(0.03)$ & $(0.005)$ & & $(0.04)$ & $(0.01)$ \\
\hline \multirow[t]{2}{*}{ Party Membership } & & -0.02 & -0.003 & & $0.04 *$ & $0.01^{*}$ \\
\hline & & $(0.02)$ & $(0.003)$ & & $(0.02)$ & $(0.003)$ \\
\hline \multirow[t]{2}{*}{ No Higher Education } & & $-0.57 *$ & $-0.14^{*}$ & & -0.67 & $-0.12 *$ \\
\hline & & $(0.32)$ & $(0.08)$ & & $(0.43)$ & $(0.07)$ \\
\hline \multirow[t]{2}{*}{ Exit } & & -0.01 & -0.001 & & -0.02 & -0.003 \\
\hline & & $(0.02)$ & $(0.003)$ & & $(0.02)$ & $(0.004)$ \\
\hline \multirow[t]{2}{*}{ Intercept } & $0.42 * *$ & $0.56^{* *}$ & $0.11^{* *}$ & $-1.12 * * *$ & $-0.91 * * *$ & $-0.15 * * *$ \\
\hline & $(0.18)$ & $(0.27)$ & $(0.05)$ & $(0.23)$ & $(0.30)$ & $(0.04)$ \\
\hline AIC & 348.6 & 352 & - & 278 & 279 & - \\
\hline Observations & 287 & 287 & 287 & 252 & 252 & 252 \\
\hline
\end{tabular}

Logistic regression models. Dependent variable: Public/Private Post-Parliamentary Positions. Robust standard errors in brackets. Continuous variables are centered around the mean, business friendly party and ISEI are also standardized. Higher education is the reference category. AME= Average Marginal Effects (discrete percentage change for binary variables). ${ }^{*} \mathrm{p}<.1 ;{ }^{* *} \mathrm{p}<.05 ;{ }^{* * *} \mathrm{p}<.01$ 
Table A9. Logistic Regression Models of Post-Parliamentary Career Success in the Netherlands with Party Variables

\begin{tabular}{|c|c|c|c|c|}
\hline & $\begin{array}{l}\text { Public } \\
\text { Model } 5\end{array}$ & $\begin{array}{l}\text { Public } \\
\text { Model } 9\end{array}$ & $\begin{array}{l}\text { Private } \\
\text { Model } 7\end{array}$ & $\begin{array}{l}\text { Private } \\
\text { Model } 10\end{array}$ \\
\hline GenderFemale & $\begin{array}{l}-0.43 \\
(0.30)\end{array}$ & $\begin{array}{l}-0.40 \\
(0.35)\end{array}$ & $\begin{array}{l}-0.41 \\
(0.35)\end{array}$ & $\begin{array}{l}-0.30 \\
(0.38)\end{array}$ \\
\hline Cabinet & $\begin{array}{l}1.92 * * * \\
(0.57)\end{array}$ & $\begin{array}{l}1.94 * * * \\
(0.62)\end{array}$ & $\begin{array}{l}2.15 * * * \\
(0.44)\end{array}$ & $\begin{array}{l}2.55 * * * \\
(0.53)\end{array}$ \\
\hline Party Position & $\begin{array}{l}-0.66 \\
(0.50)\end{array}$ & $\begin{array}{l}-0.24 \\
(0.54)\end{array}$ & $\begin{array}{l}1.23 * * \\
(0.53)\end{array}$ & $\begin{array}{l}3.16 * * * \\
(0.90)\end{array}$ \\
\hline Parliament Presidium & $\begin{array}{l}0.34 \\
(0.48)\end{array}$ & $\begin{array}{l}0.62 \\
(0.57)\end{array}$ & $\begin{array}{l}1.30 * * \\
(0.64)\end{array}$ & $\begin{array}{l}2.74 * * * \\
(0.84)\end{array}$ \\
\hline Failed Election & $\begin{array}{l}-2.40 * * * \\
(0.64)\end{array}$ & $\begin{array}{l}-2.02 * * \\
(0.90)\end{array}$ & $\begin{array}{l}-0.86 \\
(0.55)\end{array}$ & $\begin{array}{l}-0.78 \\
(0.68)\end{array}$ \\
\hline Failed Nomination & $\begin{array}{l}-2.62^{* *} \\
(1.09)\end{array}$ & $\begin{array}{l}-2.58 * * \\
(1.04)\end{array}$ & $\begin{array}{l}-1.03 \\
(0.83)\end{array}$ & $\begin{array}{l}-1.11 \\
(0.92)\end{array}$ \\
\hline Age At Exit & $\begin{array}{l}-0.03 \\
(0.02)\end{array}$ & $\begin{array}{l}-0.01 \\
(0.03)\end{array}$ & $\begin{array}{l}-0.06^{* * * *} \\
(0.02)\end{array}$ & $\begin{array}{l}-0.11 * * * \\
(0.03)\end{array}$ \\
\hline ISEI & $\begin{array}{l}0.23 * \\
(0.12)\end{array}$ & $\begin{array}{l}0.14 \\
(0.15)\end{array}$ & $\begin{array}{l}0.15 \\
(0.16)\end{array}$ & $\begin{array}{l}0.08 \\
(0.23)\end{array}$ \\
\hline Business Friendly Party & & $\begin{array}{l}0.01 \\
(0.26)\end{array}$ & & $\begin{array}{l}0.06 \\
(0.41)\end{array}$ \\
\hline Party Not in Power & & $\begin{array}{l}0.21 \\
(0.34)\end{array}$ & & $\begin{array}{l}0.27 \\
(0.47)\end{array}$ \\
\hline Business Committee & & $\begin{array}{l}0.69 \\
(0.48)\end{array}$ & & $\begin{array}{l}0.78 \\
(0.64)\end{array}$ \\
\hline Years as a MP & & $\begin{array}{l}-0.01 \\
(0.03)\end{array}$ & & $\begin{array}{l}-0.04 \\
(0.05)\end{array}$ \\
\hline Party Membership & & $\begin{array}{l}-0.02 \\
(0.02)\end{array}$ & & $\begin{array}{l}0.05^{*} \\
(0.03)\end{array}$ \\
\hline No Higher Education & & $\begin{array}{l}-0.56 \\
(0.35)\end{array}$ & & $\begin{array}{l}-0.58 \\
(0.48)\end{array}$ \\
\hline Exit & & $\begin{array}{l}0.01 \\
(0.02)\end{array}$ & & $\begin{array}{l}0.02 \\
(0.03)\end{array}$ \\
\hline partyCDA & & $\begin{array}{l}0.15 \\
(0.38)\end{array}$ & & $\begin{array}{l}-0.46 \\
(0.57)\end{array}$ \\
\hline partyD66 & & $\begin{array}{l}-0.76 \\
(0.65)\end{array}$ & & $\begin{array}{l}-0.93 \\
(0.65)\end{array}$ \\
\hline partyGroenLinks & & $\begin{array}{l}-0.36 \\
(0.79)\end{array}$ & & $\begin{array}{l}-2.60 * \\
(1.56)\end{array}$ \\
\hline partyLPF & & $\begin{array}{l}-17.53 * * * \\
(0.88)\end{array}$ & & $\begin{array}{l}-2.48 * * * \\
(0.93)\end{array}$ \\
\hline partyPVV & & $\begin{array}{l}-16.49^{* * *} \\
(0.96)\end{array}$ & & $\begin{array}{l}-15.46^{* * *} \\
(0.94)\end{array}$ \\
\hline partySP & & $\begin{array}{l}-0.23 \\
(1.16)\end{array}$ & & $\begin{array}{l}-4.32 * * \\
(1.76)\end{array}$ \\
\hline
\end{tabular}




\begin{tabular}{lllll} 
partyVVD & \multicolumn{3}{c}{0.32} & -0.37 \\
Constant & $0.42 * *$ & $(0.62)$ & $(0.93)$ \\
& $(0.18)$ & $(0.37)$ & $-1.12 * * *$ & $-0.83 *$ \\
\hline AIC & 348.6 & 344.3 & 278 & $(0.23)$ \\
Observations & 287 & 277 & 252 & 239 \\
\hline
\end{tabular}

Robust standard errors in brackets. Continuous variables are centered around the mean, business friendly party and ISEI are also standardized. Higher education and PvdA (party) are the reference categories. AME $=$ Average Marginal Effects (discrete percentage change for binary variables). ${ }^{*} \mathrm{p}<.1 ; * * \mathrm{p}<.05 ; * * * \mathrm{p}<.01$

Table A10. Logistic Regression Models of Post-Parliamentary Career Success in the Netherlands - Alternative Period

\begin{tabular}{|c|c|c|c|c|c|c|}
\hline & $\begin{array}{l}\text { Public } \\
\text { Model } 5\end{array}$ & $\begin{array}{l}\text { Public } \\
\text { Model } 11\end{array}$ & $\begin{array}{l}\text { Public } \\
\text { (AME) }\end{array}$ & $\begin{array}{l}\text { Private } \\
\text { Model } 7\end{array}$ & $\begin{array}{l}\text { Private } \\
\text { Model } 12\end{array}$ & $\begin{array}{l}\text { Private } \\
\text { (AME) }\end{array}$ \\
\hline \multirow[t]{2}{*}{ GenderFemale } & -0.43 & -0.49 & -0.12 & -0.41 & -0.52 & -0.10 \\
\hline & $(0.30)$ & $(0.36)$ & $(0.08)$ & $(0.35)$ & $(0.41)$ & $(0.76)$ \\
\hline \multirow[t]{2}{*}{ Cabinet } & $1.92 * * *$ & $2.42 * * *$ & $0.42 * * *$ & $2.15 * * *$ & $1.98 * * *$ & 0.46 \\
\hline & $(0.57)$ & $(0.64)$ & $(0.06)$ & $(0.44)$ & $(0.52)$ & $(0.48)$ \\
\hline \multirow[t]{2}{*}{ Party Position } & -0.66 & -0.31 & -0.08 & $1.23 * *$ & $2.00^{* * *}$ & $0.46^{* * *}$ \\
\hline & $(0.50)$ & $(0.52)$ & $(0.14)$ & $(0.53)$ & $(0.65)$ & $(0.18)$ \\
\hline \multirow[t]{2}{*}{ Parliament Presidium } & 0.34 & 0.85 & $0.19^{*}$ & $1.30 * *$ & $1.60 * *$ & 0.38 \\
\hline & $(0.48)$ & $(0.56)$ & $(0.10)$ & $(0.64)$ & $(0.80)$ & $(0.46)$ \\
\hline \multirow[t]{2}{*}{ Failed Election } & $-2.40 * * *$ & $-2.11 * * *$ & $-0.46 * * *$ & -0.86 & -0.98 & -0.17 \\
\hline & $(0.64)$ & $(0.73)$ & $(0.10)$ & $(0.55)$ & $(0.64)$ & $(1.48)$ \\
\hline \multirow[t]{2}{*}{ Failed Nomination } & $-2.62 * *$ & $-2.04 *$ & $-0.43 * * *$ & -1.03 & -1.12 & -0.18 \\
\hline & $(1.09)$ & $(1.06)$ & $(0.15)$ & $(0.83)$ & $(1.09)$ & $(1.69)$ \\
\hline \multirow[t]{2}{*}{ Age At Exit } & -0.03 & -0.03 & -0.005 & $-0.06^{* * *}$ & $-0.07 * * *$ & -0.01 \\
\hline & $(0.02)$ & $(0.03)$ & $(0.004)$ & $(0.02)$ & $(0.03)$ & $(0.07)$ \\
\hline \multirow[t]{2}{*}{ ISEI } & $0.23^{*}$ & 0.10 & 0.02 & 0.15 & 0.26 & 0.04 \\
\hline & $(0.12)$ & $(0.15)$ & $(0.03)$ & $(0.16)$ & $(0.22)$ & $(0.26)$ \\
\hline \multirow[t]{2}{*}{ Business Friendly Party } & & $0.31 *$ & $0.05^{*}$ & & 0.22 & 0.03 \\
\hline & & $(0.18)$ & $(0.03)$ & & $(0.20)$ & $(0.22)$ \\
\hline \multirow[t]{2}{*}{ Party Not in Power } & & -0.09 & -0.02 & & -0.42 & -0.09 \\
\hline & & $(0.34)$ & $(0.08)$ & & $(0.40)$ & $(0.60)$ \\
\hline \multirow[t]{2}{*}{ Business Committee } & & 0.74 & 0.17 & & 0.63 & 0.14 \\
\hline & & $(0.57)$ & $(0.10)$ & & $(0.60)$ & $(0.71)$ \\
\hline \multirow[t]{2}{*}{ Years as a MP } & & 0.03 & 0.004 & & -0.04 & -0.01 \\
\hline & & $(0.03)$ & $(0.005)$ & & $(0.04)$ & $(0.04)$ \\
\hline
\end{tabular}


38

Party Membership

No Higher Education

Exit

Intercept

legislative_termBalkenende II

legislative_termBalkenende III

legislative_termBalkenende IV

legislative_termKok I

legislative_termKok II

legislative_termLubbers I

legislative_termLubbers II

legislative_termRutte I

legislative_termRutte II

Constant
CLINT CLAESSEN ET AL.

$-0.01 \quad-0.002$

(0.02) (0.003)

$0.03 \quad 0.004$

$-0.71 * * \quad-0.17 * *$

(0.02) (0.03)

(0.35)

(0.08)

$-0.44$

$-0.09$

$-0.87 * * *-0.15 * * *$

(0.44)

(0.65)

$(0.21)$

$(0.04)$

$7.53 * * * \quad 0.52 * * *$

(2.20) (0.04)

$-0.61 * * \quad-0.09$

$11.46 * * * \quad 0.70 * * *$

(0.24)

4.54

0.73

(2.78)

(2.75)

(0.06)

$11.78 * * * \quad 0.49 * * *$

$8.12 * *$

0.89

(3.22)

(1.54)

$23.39 * * * \quad 0.78 * * *$

(3.17)

(0.04)

(3.58)

(0.03)

$14.64 * * * 0.83 * * *$

$9.09 * *$

0.89

(3.50)

(0.06)

(4.06)

(1.61)

$3.70 * * * \quad 0.51 * * *$

$2.57 *$

0.56

(1.08) (0.06)

(1.36)

(0.49)

$7.03 * * * \quad 0.64 * * *$

$4.98 * *$

0.82

(1.78) (0.06)

(2.28)

(1.34)

$-6.94 * * * \quad-0.71 * * *$

$-5.49 * * * \quad-0.35$

(1.92)

(0.06)

(2.00)

(3.70)

$-4.46 * * * \quad-0.62 * * *$

$-0.94$

$-0.16$

(1.31)

(0.06)

(1.70)

$15.95 * * * 0.80 * * *$

$11.48 * * \quad 0.90$

(3.95)

(0.06)

(4.60)

(1.47)

$17.19 * * * \quad 0.58 * * *$

$12.30 * * \quad 0.76$

(4.30) (0.05)

(4.79)

(2.96)

\begin{tabular}{lllllll} 
Constant & $0.42 * *$ & $-6.34 * * *$ & $-1.08 * * *$ & $-1.12 * * *$ & $-5.73 * * *$ & -0.83 \\
& $(0.18)$ & $(1.64)$ & $(0.28)$ & $(0.23)$ & $(2.08)$ & $(5.71)$ \\
\hline AIC & 348.6 & 342.7 & - & 278 & 277.6 & - \\
Observations & 287 & 287 & 287 & 252 & 252 & 252 \\
\hline
\end{tabular}

Logistic regression models. Dependent variable: Public/Private Post-Parliamentary Positions.. Higher education and Lubbers III are the reference categories. AME= Average Marginal Effects (discrete percentage change for binary variables). Robust standard errors in brackets. Continuous variables are centered around the mean, business friendly party and ISEI are also standardized. ${ }^{*} \mathrm{p}<.1 ;{ }^{* *} \mathrm{p}<.05 ;{ }^{* * *} \mathrm{p}<.01$ 


\section{Germany}


Table A11. Logistic Regression Models of Post-Parliamentary Career Success in Germany

\begin{tabular}{|c|c|c|c|c|c|c|}
\hline & $\begin{array}{l}\text { Public } \\
\text { Model } 13\end{array}$ & $\begin{array}{l}\text { Public } \\
\text { Model } 14\end{array}$ & $\begin{array}{l}\text { Public } \\
\text { (AME) }\end{array}$ & $\begin{array}{l}\text { Private } \\
\text { Model } 15\end{array}$ & $\begin{array}{l}\text { Private } \\
\text { Model } 16\end{array}$ & $\begin{array}{l}\text { Private } \\
\text { (AME) }\end{array}$ \\
\hline GenderFemale & $\begin{array}{l}-1.00^{* *} \\
(0.39)\end{array}$ & $\begin{array}{l}-0.83^{*} \\
(0.48)\end{array}$ & $\begin{array}{l}-0.16 \\
(0.27)\end{array}$ & $\begin{array}{l}-0.95 * * * \\
(0.28)\end{array}$ & $\begin{array}{l}-0.77 * * \\
(0.31)\end{array}$ & $\begin{array}{l}-0.09 * * * \\
(0.03)\end{array}$ \\
\hline Cabinet & $\begin{array}{l}0.66 \\
(0.52)\end{array}$ & $\begin{array}{l}0.83 \\
(0.57)\end{array}$ & $\begin{array}{l}0.19 \\
(0.22)\end{array}$ & $\begin{array}{l}0.48 \\
(0.41)\end{array}$ & $\begin{array}{l}0.69 \\
(0.44)\end{array}$ & $\begin{array}{l}0.11 \\
(0.09)\end{array}$ \\
\hline Party Position & $\begin{array}{l}1.07 * * * \\
(0.38)\end{array}$ & $\begin{array}{l}1.27 * * * \\
(0.42)\end{array}$ & $\begin{array}{l}0.29 \\
(0.26)\end{array}$ & $\begin{array}{l}1.10 * * * \\
(0.37)\end{array}$ & $\begin{array}{l}1.11 * * * \\
(0.40)\end{array}$ & $\begin{array}{l}0.19 * * \\
(0.08)\end{array}$ \\
\hline Parliament Presidium & $\begin{array}{l}14.89 * * * \\
(1.10)\end{array}$ & $\begin{array}{l}14.44 * * * \\
(1.23)\end{array}$ & $\begin{array}{l}0.72 * * * \\
(0.04)\end{array}$ & $\begin{array}{l}0.34 \\
(1.03)\end{array}$ & $\begin{array}{l}-0.39 \\
(0.95)\end{array}$ & $\begin{array}{l}-0.04 \\
(0.14)\end{array}$ \\
\hline Failed Election & $\begin{array}{l}-2.10 * * * \\
(0.42)\end{array}$ & $\begin{array}{l}-1.99 * * * \\
(0.46)\end{array}$ & $\begin{array}{l}-0.36 \\
(0.55)\end{array}$ & $\begin{array}{l}-0.90 * * * \\
(0.29)\end{array}$ & $\begin{array}{l}-0.55^{*} \\
(0.33)\end{array}$ & $\begin{array}{l}-0.07 * \\
(0.04)\end{array}$ \\
\hline Failed Nomination & $\begin{array}{l}-2.03 * \\
(1.14)\end{array}$ & $\begin{array}{l}-2.32 * * \\
(1.06)\end{array}$ & $\begin{array}{l}-0.27 \\
(0.62)\end{array}$ & $\begin{array}{l}-1.49 * * \\
(0.73)\end{array}$ & $\begin{array}{l}-1.39 \\
(0.92)\end{array}$ & $\begin{array}{l}-0.12 * * * \\
(0.04)\end{array}$ \\
\hline Age At Exit & $\begin{array}{l}-0.05^{* *} \\
(0.02)\end{array}$ & $\begin{array}{l}-0.02 \\
(0.02)\end{array}$ & $\begin{array}{l}-0.003 \\
(0.01)\end{array}$ & $\begin{array}{l}-0.04 * * * \\
(0.01)\end{array}$ & $\begin{array}{l}-0.05 * * * \\
(0.02)\end{array}$ & $\begin{array}{l}-0.01 * * * \\
(0.002)\end{array}$ \\
\hline ISEI & $\begin{array}{l}0.50 * * * \\
(0.18)\end{array}$ & $\begin{array}{l}0.30 \\
(0.20)\end{array}$ & $\begin{array}{l}0.04 \\
(0.07)\end{array}$ & $\begin{array}{l}0.16 \\
(0.13)\end{array}$ & $\begin{array}{l}0.09 \\
(0.13)\end{array}$ & $\begin{array}{l}0.01 \\
(0.02)\end{array}$ \\
\hline Business Friendly Party & & $\begin{array}{l}0.36^{* *} \\
(0.18)\end{array}$ & $\begin{array}{l}0.05 \\
(0.08)\end{array}$ & & $\begin{array}{l}-0.05 \\
(0.16)\end{array}$ & $\begin{array}{l}-0.01 \\
(0.02)\end{array}$ \\
\hline Party Not in Power & & $\begin{array}{l}0.12 \\
(0.37)\end{array}$ & $\begin{array}{l}0.02 \\
(0.09)\end{array}$ & & $\begin{array}{l}-0.04 \\
(0.29)\end{array}$ & $\begin{array}{l}-0.005 \\
(0.04)\end{array}$ \\
\hline Business Committee & & $\begin{array}{l}-0.91 \\
(0.65)\end{array}$ & $\begin{array}{l}-0.16 \\
(0.31)\end{array}$ & & $\begin{array}{l}1.38 * * * \\
(0.34)\end{array}$ & $\begin{array}{l}0.25 * * * \\
(0.07)\end{array}$ \\
\hline Years as a MP & & $\begin{array}{l}-0.05 \\
(0.04)\end{array}$ & $\begin{array}{l}-0.01 \\
(0.01)\end{array}$ & & $\begin{array}{l}0.07 * * * \\
(0.02)\end{array}$ & $\begin{array}{l}0.01 * * * \\
(0.003)\end{array}$ \\
\hline Party Membership & & $\begin{array}{l}-0.01 \\
(0.02)\end{array}$ & $\begin{array}{l}-0.002 \\
(0.004)\end{array}$ & & $\begin{array}{l}0.01 \\
(0.02)\end{array}$ & $\begin{array}{l}0.002 \\
(0.002)\end{array}$ \\
\hline No Higher Education & & $\begin{array}{l}-1.16^{* * *} \\
(0.42)\end{array}$ & $\begin{array}{l}-0.22 \\
(0.36)\end{array}$ & & $\begin{array}{l}-0.55^{*} \\
(0.31)\end{array}$ & $\begin{array}{l}-0.07 * \\
(0.04)\end{array}$ \\
\hline Exit & & $\begin{array}{l}-0.12 * * \\
(0.05)\end{array}$ & $\begin{array}{l}-0.02 \\
(0.03)\end{array}$ & & $\begin{array}{l}-0.01 \\
(0.04)\end{array}$ & $\begin{array}{l}-0.001 \\
(0.005)\end{array}$ \\
\hline Intercept & $\begin{array}{l}-0.08 \\
(0.24) \\
\end{array}$ & $\begin{array}{l}0.16 \\
(0.32) \\
\end{array}$ & $\begin{array}{l}0.02 \\
(0.06)\end{array}$ & $\begin{array}{l}-0.96^{* * *} \\
(0.19)\end{array}$ & $\begin{array}{l}-1.26^{* * *} \\
(0.28)\end{array}$ & $\begin{array}{l}-0.16^{* * *} \\
(0.04)\end{array}$ \\
\hline $\mathrm{AIC}$ & 264.3 & 257.7 & - & 451.7 & 427.2 & - \\
\hline Observations & 251 & 251 & 251 & 474 & 474 & 474 \\
\hline
\end{tabular}

Logistic regression models. Dependent variable: Public/Private Post-Parliamentary Positions. Robust standard errors in brackets. Continuous variables are centered around the mean, business friendly party and ISEI are also standardized. Higher education is the reference category. AME $=$ Average Marginal Effects (discrete percentage change for binary variables). ${ }^{*} \mathrm{p}<.1 ;{ }^{* *} \mathrm{p}<.05 ;{ }^{* * *} \mathrm{p}<.01$ 
Table A12. Logistic Regression Models of Post-Parliamentary Career Success in Germany with Party variables

\begin{tabular}{|c|c|c|c|c|}
\hline & $\begin{array}{l}\text { Public } \\
\text { Model } \\
13\end{array}$ & $\begin{array}{l}\text { Private } \\
\text { Model } \\
17\end{array}$ & $\begin{array}{l}\text { Private } \\
\text { Model } \\
15\end{array}$ & $\begin{array}{l}\text { Private } \\
\text { Model } 18\end{array}$ \\
\hline GenderFemale & $\begin{array}{l}-1.00^{* *} \\
(0.39)\end{array}$ & $\begin{array}{l}-1.03 * * \\
(0.51)\end{array}$ & $\begin{array}{l}-0.95^{* * *} \\
(0.28)\end{array}$ & $\begin{array}{l}*-0.77 * * \\
(0.32)\end{array}$ \\
\hline Cabinet & $\begin{array}{l}0.66 \\
(0.52)\end{array}$ & $\begin{array}{l}0.97^{*} \\
(0.58)\end{array}$ & $\begin{array}{l}0.48 \\
(0.41)\end{array}$ & $\begin{array}{l}0.80^{*} \\
(0.45)\end{array}$ \\
\hline Party Position & $\begin{array}{l}1.07 * * * \\
(0.38)\end{array}$ & $\begin{array}{l}1.46^{* * *} \\
(0.44)\end{array}$ & $\begin{array}{l}1.10^{* * *} \\
(0.37)\end{array}$ & $\begin{array}{l}1.17^{* * *} \\
(0.40)\end{array}$ \\
\hline Parliament Presidium & $\begin{array}{l}14.89^{* *} \\
* \\
(1.10)\end{array}$ & $\begin{array}{l}14.62 * * \\
* \\
(1.27)\end{array}$ & $\begin{array}{l}0.34 \\
(1.03)\end{array}$ & $\begin{array}{l}-0.39 \\
(1.05)\end{array}$ \\
\hline Failed Election & $\begin{array}{l}-2.10^{* * *} \\
(0.42)\end{array}$ & $\begin{array}{l}-1.87 * * * \\
(0.48)\end{array}$ & $\begin{array}{l}*-0.90^{* * *} \\
(0.29)\end{array}$ & $\begin{array}{l}{ }^{*}-0.38 \\
(0.34)\end{array}$ \\
\hline Failed Nomination & $\begin{array}{l}-2.03 * \\
(1.14)\end{array}$ & $\begin{array}{l}-2.23^{*} \\
(1.18)\end{array}$ & $\begin{array}{l}-1.49^{* *} \\
(0.73)\end{array}$ & $\begin{array}{l}-1.34 \\
(0.92)\end{array}$ \\
\hline Age At Exit & $\begin{array}{l}-0.05^{* *} \\
(0.02)\end{array}$ & $\begin{array}{l}-0.01 \\
(0.02)\end{array}$ & $\begin{array}{l}-0.04 * * * \\
(0.01)\end{array}$ & $\begin{array}{l}* 0.05^{* * *} \\
(0.02)\end{array}$ \\
\hline ISEI & $\begin{array}{l}0.50^{* * *} \\
(0.18)\end{array}$ & $\begin{array}{l}0.36^{*} \\
(0.20)\end{array}$ & $\begin{array}{l}0.16 \\
(0.13)\end{array}$ & $\begin{array}{l}0.14 \\
(0.13)\end{array}$ \\
\hline Business Friendly Party & & $\begin{array}{l}0.40 \\
(0.39)\end{array}$ & & $\begin{array}{l}0.22 \\
(0.37)\end{array}$ \\
\hline Party Not in Power & & $\begin{array}{l}0.53 \\
(0.56)\end{array}$ & & $\begin{array}{l}0.43 \\
(0.47)\end{array}$ \\
\hline Business Committee & & $\begin{array}{l}-0.94 \\
(0.69)\end{array}$ & & $\begin{array}{l}1.37^{* * *} \\
(0.35)\end{array}$ \\
\hline Years as a MP & & $\begin{array}{l}-0.06 \\
(0.04)\end{array}$ & & $\begin{array}{l}0.07 * * * \\
(0.02)\end{array}$ \\
\hline Party Membership & & $\begin{array}{l}-0.01 \\
(0.02)\end{array}$ & & $\begin{array}{l}0.01 \\
(0.02)\end{array}$ \\
\hline No Higher Education & & $\begin{array}{l}-1.08^{* *} \\
(0.45)\end{array}$ & & $\begin{array}{l}-0.57^{*} \\
(0.32)\end{array}$ \\
\hline Exit & & $\begin{array}{l}-0.11^{*} \\
(0.06)\end{array}$ & & $\begin{array}{l}-0.01 \\
(0.04)\end{array}$ \\
\hline partyB90/GR & & $\begin{array}{l}0.35 \\
(0.84)\end{array}$ & & $\begin{array}{l}0.31 \\
(0.55)\end{array}$ \\
\hline partyCDU & & $\begin{array}{l}-0.14 \\
(0.86)\end{array}$ & & $\begin{array}{l}-0.22 \\
(0.68)\end{array}$ \\
\hline partyCSU & & $\begin{array}{l}-0.53 \\
(1.00)\end{array}$ & & $\begin{array}{l}-1.12 \\
(0.92)\end{array}$ \\
\hline
\end{tabular}


partyFDP

$$
-0.94
$$

partyLinke

Constant

$$
\begin{array}{ll}
-0.08 \quad 0.16
\end{array}
$$

AIC

$(0.24)$

$(0.48)$

264.3

262.8

451.7

$(0.40)$

Observations 251

250
474

473

Logistic regression models. Dependent variable: Public/Private Post-Parliamentary Positions.

Robust standard errors in brackets. Continuous variables are centered around the mean, business friendly party and ISEI are also standardized. Higher education and SPD (party) are the reference categories. AME $=$ Average Marginal Effects (discrete percentage change for binary variables). ${ }^{*} \mathrm{p}<.1 ;{ }^{* *} \mathrm{p}<.05 ;{ }^{* * *} \mathrm{p}<.01$

\begin{tabular}{|c|c|c|c|c|c|c|}
\hline & $\begin{array}{l}\text { Public } \\
\text { Model } 13\end{array}$ & $\begin{array}{l}\text { Public } \\
\text { Model } 19\end{array}$ & $\begin{array}{l}\text { Public } \\
\text { (AME) }\end{array}$ & $\begin{array}{l}\text { Private } \\
\text { Model } 15\end{array}$ & $\begin{array}{l}\text { Private } \\
\text { Model } 20\end{array}$ & $\begin{array}{l}\text { Private } \\
\text { (AME) }\end{array}$ \\
\hline GenderFemale & $\begin{array}{l}-1.00^{* *} \\
(0.39)\end{array}$ & $\begin{array}{l}-0.72 \\
(0.49)\end{array}$ & $\begin{array}{l}-0.14 \\
(0.24)\end{array}$ & $\begin{array}{l}-0.95^{* * *} \\
(0.28)\end{array}$ & $\begin{array}{l}-0.76^{* *} \\
(0.31)\end{array}$ & $\begin{array}{l}-0.09 * * * \\
(0.04)\end{array}$ \\
\hline Cabinet & $\begin{array}{l}0.66 \\
(0.52)\end{array}$ & $\begin{array}{l}0.71 \\
(0.63)\end{array}$ & $\begin{array}{l}0.16 \\
(0.22)\end{array}$ & $\begin{array}{l}0.48 \\
(0.41)\end{array}$ & $\begin{array}{l}0.74 * \\
(0.45)\end{array}$ & $\begin{array}{l}0.12 \\
(0.09)\end{array}$ \\
\hline Party Position & $\begin{array}{l}1.07 * * * \\
(0.38)\end{array}$ & $\begin{array}{l}1.27 * * * \\
(0.44)\end{array}$ & $\begin{array}{l}0.29 \\
(0.25)\end{array}$ & $\begin{array}{l}1.10^{* * * *} \\
(0.37)\end{array}$ & $\begin{array}{l}1.07^{* * *} \\
(0.41)\end{array}$ & $\begin{array}{l}0.18^{* *} \\
(0.08)\end{array}$ \\
\hline Parliament Presidium & $\begin{array}{l}14.89^{* * *} \\
(1.10)\end{array}$ & $\begin{array}{l}15.03 * * * \\
(1.31)\end{array}$ & $\begin{array}{l}0.72 * * * \\
(0.04)\end{array}$ & $\begin{array}{l}0.34 \\
(1.03)\end{array}$ & $\begin{array}{l}-0.30 \\
(0.99)\end{array}$ & $\begin{array}{l}-0.04 \\
(0.15)\end{array}$ \\
\hline Failed Election & $\begin{array}{l}-2.10 * * * \\
(0.42)\end{array}$ & $\begin{array}{l}-1.68 * * * \\
(0.47)\end{array}$ & $\begin{array}{l}-0.31 \\
(0.48)\end{array}$ & $\begin{array}{l}-0.90 * * * \\
(0.29)\end{array}$ & $\begin{array}{l}-0.45 \\
(0.33)\end{array}$ & $\begin{array}{l}-0.06 \\
(0.04)\end{array}$ \\
\hline Failed Nomination & $\begin{array}{l}-2.03^{*} \\
(1.14)\end{array}$ & $\begin{array}{l}-1.82 * \\
(0.99)\end{array}$ & $\begin{array}{l}-0.24 \\
(0.54)\end{array}$ & $\begin{array}{l}-1.49^{* *} \\
(0.73)\end{array}$ & $\begin{array}{l}-1.25 \\
(0.93)\end{array}$ & $\begin{array}{l}-0.11^{* *} \\
(0.04)\end{array}$ \\
\hline Age At Exit & $\begin{array}{l}-0.05^{* *} \\
(0.02)\end{array}$ & $\begin{array}{l}-0.01 \\
(0.02)\end{array}$ & $\begin{array}{l}-0.002 \\
(0.004)\end{array}$ & $\begin{array}{l}-0.04 * * * \\
(0.01)\end{array}$ & $\begin{array}{l}-0.05 * * * \\
(0.02)\end{array}$ & $\begin{array}{l}-0.01 * * * \\
(0.002)\end{array}$ \\
\hline ISEI & $\begin{array}{l}0.50 * * * \\
(0.18)\end{array}$ & $\begin{array}{l}0.41 * \\
(0.22)\end{array}$ & $\begin{array}{l}0.06 \\
(0.09)\end{array}$ & $\begin{array}{l}0.16 \\
(0.13)\end{array}$ & $\begin{array}{l}0.09 \\
(0.14)\end{array}$ & $\begin{array}{l}0.01 \\
(0.02)\end{array}$ \\
\hline Business Friendly Party & & $\begin{array}{l}0.26 \\
(0.19)\end{array}$ & $\begin{array}{l}0.04 \\
(0.06)\end{array}$ & & $\begin{array}{l}-0.11 \\
(0.16)\end{array}$ & $\begin{array}{l}-0.01 \\
(0.02)\end{array}$ \\
\hline Party Not in Power & & $\begin{array}{l}0.03 \\
(0.40)\end{array}$ & $\begin{array}{l}0.005 \\
(0.08)\end{array}$ & & $\begin{array}{l}0.02 \\
(0.33)\end{array}$ & $\begin{array}{l}0.002 \\
(0.04)\end{array}$ \\
\hline
\end{tabular}

Table A13. Logistic Regression Models of Post-Parliamentary Career Success in Germany - Alternative Period 


\begin{tabular}{|c|c|c|c|c|c|c|}
\hline Business Committee & & $\begin{array}{l}-0.95 \\
(0.69)\end{array}$ & $\begin{array}{l}-0.17 \\
(0.32)\end{array}$ & & $\begin{array}{l}1.44 * * * \\
(0.34)\end{array}$ & $\begin{array}{l}0.26^{* * *} \\
(0.07)\end{array}$ \\
\hline Years as a MP & & $\begin{array}{l}-0.05 \\
(0.04)\end{array}$ & $\begin{array}{l}-0.01 \\
(0.01)\end{array}$ & & $\begin{array}{l}0.07 * * * \\
(0.02)\end{array}$ & $\begin{array}{l}0.01 * * * \\
(0.003)\end{array}$ \\
\hline Party Membership & & $\begin{array}{l}-0.01 \\
(0.02)\end{array}$ & $\begin{array}{l}-0.002 \\
(0.004)\end{array}$ & & $\begin{array}{l}0.02 \\
(0.02)\end{array}$ & $\begin{array}{l}0.002 \\
(0.002)\end{array}$ \\
\hline No Higher Education & & $\begin{array}{l}-1.19^{* *} \\
(0.46)\end{array}$ & $\begin{array}{l}-0.22 \\
(0.37)\end{array}$ & & $\begin{array}{l}-0.57^{*} \\
(0.31)\end{array}$ & $\begin{array}{l}-0.07 * \\
(0.04)\end{array}$ \\
\hline Exit & & $\begin{array}{l}-1.15^{* * *} \\
(0.43)\end{array}$ & $\begin{array}{l}-0.16 \\
(0.24)\end{array}$ & & $\begin{array}{l}-0.63 * * \\
(0.32)\end{array}$ & $\begin{array}{l}-0.08^{*} \\
(0.05)\end{array}$ \\
\hline legislative_termMerkel I & & $\begin{array}{l}-4.51 * * \\
(1.94)\end{array}$ & $\begin{array}{l}-0.59 \\
(0.79)\end{array}$ & & $\begin{array}{l}-2.52 * \\
(1.47)\end{array}$ & $\begin{array}{l}-0.22 * * \\
(0.10)\end{array}$ \\
\hline legislative_termSchröder I & & $\begin{array}{l}-12.27 * * \\
(4.92)\end{array}$ & $\begin{array}{l}-0.89^{* *} \\
(0.35)\end{array}$ & & $\begin{array}{l}-7.04 * \\
(3.66)\end{array}$ & $\begin{array}{l}-0.62^{* *} \\
(0.30)\end{array}$ \\
\hline legislative_termSchröder II & & $\begin{array}{l}-8.14 * * \\
(3.58)\end{array}$ & $\begin{array}{l}-0.71 \\
(0.74)\end{array}$ & & $\begin{array}{l}-4.84 * \\
(2.68)\end{array}$ & $\begin{array}{l}-0.30^{* *} \\
(0.13)\end{array}$ \\
\hline Constant & $\begin{array}{l}-0.08 \\
(0.24) \\
\end{array}$ & $\begin{array}{l}6.15^{* *} \\
(2.58)\end{array}$ & $\begin{array}{l}0.85 \\
(1.26) \\
\end{array}$ & $\begin{array}{l}-0.96 * * * \\
(0.19)\end{array}$ & $\begin{array}{l}2.28 \\
(1.93) \\
\end{array}$ & $\begin{array}{l}0.30 \\
(0.28) \\
\end{array}$ \\
\hline AIC & 264.3 & 252.1 & - & 451.7 & 429.3 & - \\
\hline Observations & 251 & 251 & 251 & 474 & 474 & 474 \\
\hline
\end{tabular}

Logistic regression models. Dependent variable: Public/Private Post-Parliamentary Positions. Robust standard errors in brackets. Continuous variables are centered around the mean, business friendly party and ISEI are also standardized. Higher education and Merkel II are the reference categories. AME $=$ Average Marginal Effects (discrete percentage change for binary variables). Public (AME) high SE due to to case limit Parliament Presidium. ${ }^{*} \mathrm{p}<.1 ;{ }^{* *} \mathrm{p}<.05$; ${ }^{* * *} \mathrm{p}<.01$ 


\section{Limited Sample}


Table A14. Logistic Regression Models of Post-Parliamentary Career Success - 1998-2015

\begin{tabular}{|c|c|c|c|c|c|c|}
\hline & $\begin{array}{l}\text { Public } \\
\text { Model } 21\end{array}$ & $\begin{array}{l}\text { Public } \\
\text { Model } 22\end{array}$ & $\begin{array}{l}\text { Public } \\
\text { (AME) }\end{array}$ & $\begin{array}{l}\text { Private } \\
\text { Model } 23\end{array}$ & $\begin{array}{l}\text { Private } \\
\text { Model } 24\end{array}$ & $\begin{array}{l}\text { Private } \\
\text { (AME) }\end{array}$ \\
\hline GenderFemale & $\begin{array}{l}-0.66 * * \\
(0.26)\end{array}$ & $\begin{array}{l}-0.50 * \\
(0.29)\end{array}$ & $\begin{array}{l}-0.12 * \\
(0.06)\end{array}$ & $\begin{array}{l}-0.71 * * * \\
(0.22)\end{array}$ & $\begin{array}{l}-0.62 * * * \\
(0.24)\end{array}$ & $\begin{array}{l}-0.08 * * * \\
(0.03)\end{array}$ \\
\hline Cabinet & $\begin{array}{l}1.24 * * * \\
(0.41)\end{array}$ & $\begin{array}{l}1.09 * * * \\
(0.42)\end{array}$ & $\begin{array}{l}0.27 * * * \\
(0.10)\end{array}$ & $\begin{array}{l}1.20 * * * \\
(0.30)\end{array}$ & $\begin{array}{l}1.21 * * * \\
(0.33)\end{array}$ & $\begin{array}{l}0.23 * * * \\
(0.08)\end{array}$ \\
\hline Party Position & $\begin{array}{l}0.72 * * \\
(0.32)\end{array}$ & $\begin{array}{l}0.80 * * \\
(0.34)\end{array}$ & $\begin{array}{l}0.20 * * \\
(0.08)\end{array}$ & $\begin{array}{l}1.02 * * * \\
(0.31)\end{array}$ & $\begin{array}{l}1.05 * * * \\
(0.34)\end{array}$ & $\begin{array}{l}0.20 * * * \\
(0.07)\end{array}$ \\
\hline Parliament Presidium & $\begin{array}{l}0.56 \\
(0.68)\end{array}$ & $\begin{array}{l}0.45 \\
(0.69)\end{array}$ & $\begin{array}{l}0.11 \\
(0.15)\end{array}$ & $\begin{array}{l}0.93 \\
(0.59)\end{array}$ & $\begin{array}{l}0.83 \\
(0.60)\end{array}$ & $\begin{array}{l}0.15 \\
(0.15)\end{array}$ \\
\hline Failed Election & $\begin{array}{l}-2.25 * * * \\
(0.33)\end{array}$ & $\begin{array}{l}-2.22 * * * \\
(0.35)\end{array}$ & $\begin{array}{l}-0.42 * * * \\
(0.05)\end{array}$ & $\begin{array}{l}-0.88 * * * \\
(0.25)\end{array}$ & $\begin{array}{l}-0.81 * * * \\
(0.28)\end{array}$ & $\begin{array}{l}-0.11 * * * \\
(0.03)\end{array}$ \\
\hline Failed Nomination & $\begin{array}{l}-2.10 * * * \\
(0.81)\end{array}$ & $\begin{array}{l}-2.11 * * * \\
(0.73)\end{array}$ & $\begin{array}{l}-0.34 * * * \\
(0.06)\end{array}$ & $\begin{array}{l}-1.47^{* *} \\
(0.61)\end{array}$ & $\begin{array}{l}-1.39 * * \\
(0.66)\end{array}$ & $\begin{array}{l}-0.14 * * * \\
(0.04)\end{array}$ \\
\hline Age At Exit & $\begin{array}{l}-0.06 * * * \\
(0.01)\end{array}$ & $\begin{array}{l}-0.05 * * * \\
(0.02)\end{array}$ & $\begin{array}{l}-0.01 * * * \\
(0.003)\end{array}$ & $\begin{array}{l}-0.04 * * * \\
(0.01)\end{array}$ & $\begin{array}{l}-0.07 * * * \\
(0.01)\end{array}$ & $\begin{array}{l}-0.01 * * * \\
(0.002)\end{array}$ \\
\hline ISEI & $\begin{array}{l}0.30 * * \\
(0.12)\end{array}$ & $\begin{array}{l}0.16 \\
(0.14)\end{array}$ & $\begin{array}{l}0.03 \\
(0.02)\end{array}$ & $\begin{array}{l}0.16 \\
(0.11)\end{array}$ & $\begin{array}{l}0.07 \\
(0.11)\end{array}$ & $\begin{array}{l}0.01 \\
(0.02)\end{array}$ \\
\hline Business Friendly Party & & $\begin{array}{l}0.31 * * \\
(0.13)\end{array}$ & $\begin{array}{l}0.05 * * \\
(0.02)\end{array}$ & & $\begin{array}{l}0.15 \\
(0.12)\end{array}$ & $\begin{array}{l}0.02 \\
(0.02)\end{array}$ \\
\hline Party Not in Power & & $\begin{array}{l}-0.01 \\
(0.26)\end{array}$ & $\begin{array}{l}-0.002 \\
(0.06)\end{array}$ & & $\begin{array}{l}-0.34 \\
(0.24)\end{array}$ & $\begin{array}{l}-0.05 \\
(0.03)\end{array}$ \\
\hline Business Committee & & $\begin{array}{l}-0.40 \\
(0.43)\end{array}$ & $\begin{array}{l}-0.09 \\
(0.09)\end{array}$ & & $\begin{array}{l}1.17 * * * \\
(0.30)\end{array}$ & $\begin{array}{l}0.22 * * * \\
(0.06)\end{array}$ \\
\hline Years as a MP & & $\begin{array}{l}-0.002 \\
(0.02)\end{array}$ & $\begin{array}{l}0.00 \\
(0.004)\end{array}$ & & $\begin{array}{l}0.06^{* * *} \\
(0.02)\end{array}$ & $\begin{array}{l}0.01 * * * \\
(0.002)\end{array}$ \\
\hline Party Membership & & $\begin{array}{l}-0.01 \\
(0.01)\end{array}$ & $\begin{array}{l}-0.001 \\
(0.002)\end{array}$ & & $\begin{array}{l}0.02 \\
(0.01)\end{array}$ & $\begin{array}{l}0.003 \\
(0.002)\end{array}$ \\
\hline No Higher Education & & $\begin{array}{l}-0.77 * * * \\
(0.28)\end{array}$ & $\begin{array}{l}-0.18 * * * \\
(0.06)\end{array}$ & & $\begin{array}{l}-0.65 * * \\
(0.25)\end{array}$ & $\begin{array}{l}-0.09 * * * \\
(0.03)\end{array}$ \\
\hline Exit & & $\begin{array}{l}-0.06 * * \\
(0.03)\end{array}$ & $\begin{array}{l}-0.01 * * \\
(0.005)\end{array}$ & & $\begin{array}{l}-0.03 \\
(0.03)\end{array}$ & $\begin{array}{l}-0.004 \\
(0.004)\end{array}$ \\
\hline Intercept & $\begin{array}{l}0.18 \\
(0.16)\end{array}$ & $\begin{array}{l}0.43^{*} \\
(0.24)\end{array}$ & $\begin{array}{l}0.08^{*} \\
(0.04)\end{array}$ & $\begin{array}{l}-1.00 * * * \\
(0.15)\end{array}$ & $\begin{array}{l}-0.93 * * * \\
(0.21)\end{array}$ & $\begin{array}{l}-0.13 * * * \\
(0.03)\end{array}$ \\
\hline AIC & 461.9 & 458.7 & - & 634.6 & 604.5 & - \\
\hline Observations & 411 & 411 & 411 & 647 & 647 & 647 \\
\hline
\end{tabular}


Logistic regression models. Dependent variable: Public/Private Post-Parliamentary Positions. Robust standard errors in brackets. Continuous variables are centered around the mean, business friendly party and ISEI are also standardized. Higher education is the reference category. $\mathrm{AME}=$ Average Marginal Effects (discrete percentage change for binary variables). ${ }^{*} \mathrm{p}<.1 ;{ }^{* *} \mathrm{p}<.05 ;{ }^{* * *} \mathrm{p}<.01$ 